NBER WORKING PAPER SERIES

\title{
THE LABOR MARKET EFFECTS OF REFUGEE WAVES: RECONCILING CONFLICTING RESULTS
}

\author{
Michael A. Clemens \\ Jennifer Hunt \\ Working Paper 23433 \\ http://www.nber.org/papers/w23433 \\ NATIONAL BUREAU OF ECONOMIC RESEARCH \\ 1050 Massachusetts Avenue \\ Cambridge, MA 02138 \\ May 2017, Revised July 2017
}

\begin{abstract}
We received helpful comments from Samuel Bazzi, David Card, Ryan Edwards, Rachel Friedberg, Barry Hirsch, Fabian Lange, Ethan Lewis, Giovanni Peri, Hannah Postel, Edwin Robison, Justin Sandefur, two anonymous referees, and from seminar participants at the Barcelona Graduate School of Economics and King's College London, but any errors are ours alone. We are grateful to the IPUMS project and to Rachel Friedberg, George Borjas, and Joan Monras for making data and code available to researchers. Clemens thanks the Open Philanthropy Project and Global Affairs Canada for support; Hunt is grateful to the James Cullen Chair in Economics for support. Hunt is also affiliated with the CEPR (London) and DIW-Berlin. This paper represents the views of the authors only and should not be attributed to any institutions with which they are affiliated. This paper represents the views of the authors only and should not be attributed to any institutions with which they are affiliated, nor to the National Bureau of Economic Research.
\end{abstract}

NBER working papers are circulated for discussion and comment purposes. They have not been peer-reviewed or been subject to the review by the NBER Board of Directors that accompanies official NBER publications.

(C) 2017 by Michael A. Clemens and Jennifer Hunt. All rights reserved. Short sections of text, not to exceed two paragraphs, may be quoted without explicit permission provided that full credit, including $\odot$ notice, is given to the source. 
The Labor Market Effects of Refugee Waves: Reconciling Conflicting Results

Michael A. Clemens and Jennifer Hunt

NBER Working Paper No. 23433

May 2017, Revised July 2017

JEL No. C36,J61,R23

\begin{abstract}
$\underline{\text { ABSTRACT }}$
An influential strand of research has tested for the effects of immigration on natives' wages and employment using exogenous refugee supply shocks as natural experiments. Several studies have reached conflicting conclusions about the effects of noted refugee waves such as the Mariel Boatlift in Miami and post-Soviet refugees to Israel. We show that conflicting findings on the effects of the Mariel Boatlift can be explained by a large difference in the pre- and post-Boatlift racial composition in subsamples of the Current Population Survey extracts. This compositional change is specific to Miami, unrelated to the Boatlift, and arises from selecting small subsamples of workers. We also show that conflicting findings on the labor market effects of other important refugee waves are caused by spurious correlation between the instrument and the endogenous variable introduced by applying a common divisor to both. As a whole, the evidence from refugee waves reinforces the existing consensus that the impact of immigration on average native-born workers is small, and fails to substantiate claims of large detrimental impacts on workers with less than high school.
\end{abstract}

Michael A. Clemens

Center for Global Development

2055 L Street NW, 5th floor

Washington, DC 20036

and IZA

mclemens@cgdev.org

Jennifer Hunt

Department of Economics

Rutgers University

New Jersey Hall

75 Hamilton Street

New Brunswick, NJ 08901-1248

and IZA, CEPR, DIW-Berlin

and also NBER

Jennifer.hunt@rutgers.edu 


\section{Introduction}

A long literature in labor economics has reached something of a consensus that the effects of immigration on average native workers' wages and employment is generally small or zero. ${ }^{1}$ There is less consensus on the narrower question of the impact of immigration on less-skilled workers: Blau and Mackie, eds (2016) conclude that the effect of immigration on wages of U.S. workers with less than high school is negative, but do not reach consensus on the magnitude of the effect.

An influential strand of research has tested for labor market effects on natives using exogenous refugee supply shocks as natural experiments. Small or null effects on average native workers have been found following large refugee inflows such as those in 1980s Miami (Card 1990), 1960s France (Hunt 1992), 1990s Israel (Friedberg 2001), and in the 1990s across Europe (Angrist and Kugler 2003). But a subsequent and important strand of research has revisited those earlier works, debating whether they missed impacts on subgroups of natives such as the least skilled (Borjas 2017; Peri and Yasenov 2017), relied on inadequate causal identification (Angrist and Krueger 1999), or both (Borjas and Monras 2017). The discordant findings in this literature have not been reconciled.

In this paper we offer two new explanations for the conflicting results in all of the above studies. One is large compositional changes in the underlying survey data introduced by the selection of narrow subgroups of workers to study; the other is specification choices in the use of instrumental variables. Accounting for these differences can reduce or even eliminate substantial disagreement on the labor market effects of refugee waves in this literature.

First, we show that the discrepancy between Card's (1990) and Borjas's (2017) analyses of the 1980 Mariel Boatlift can be explained by a simultaneous large increase in the share of blacks in the small subgroup of Miami workers of concern to Borjas. The fraction of blacks is much higher in the post- than pre-Boatlift years in Borjas's Miami sample of prime-age,

\footnotetext{
${ }^{1}$ See the National Academies consensus report for the United States (Blau and Mackie, eds 2016, 204), or the survey by Kerr and Kerr (2011) including both the U.S. and Northern Europe.
} 
male, non-Hispanic workers with less than high school, while there is no such difference in Card's Miami sample of non-Cuban workers with high school or less, nor in the control cities favored by either Card or Borjas. This compositional change offers an explanation for the previous finding of Peri and Yasenov (2017), that the Borjas result is sensitive to selecting a small subset of workers. We suggest three reasons for the compositional change, including the 1980 arrival of black Haitians with less than high school and improved survey coverage of low-wage black males already in the United States.

Because both Haitian blacks and U.S. blacks had lower wages than other workers with less than high school, this compositional change tends to produce a spurious fall in average wages for workers with less than high school. Our reanalysis of Borjas's sample with an adjustment for the share of blacks yields results similar to those of Card (1990) and Peri and Yasenov (2017): little to no wage impact of the Mariel Boatlift is discernable. The change in share of blacks can also explain other features of the recent reanalyses. For example, both Borjas (2017) and Peri and Yasenov (2017) estimate wage effects of the Boatlift using two different extracts of the Current Population Survey (CPS). They find wage declines roughly three times larger in one extract than the other extract. The postBoatlift rise in the black fraction of the survey subsample is, likewise, about three times larger in one extract than the other.

Second, we show that the Borjas and Monras (2017) applications of instrumental variables to revisit the effects of the Mariel Boatlift and three other refugee waves - in France, Israel, and across Europe - give similar results to the original studies after a specification correction. We show that the instrument used by Borjas and Monras, with which they find larger harmful effects on native workers than found in some of the original studies, gives results that can be reproduced with a placebo instrument. The Borjas and Monras instrument rests on the attraction of new migrants to the locations of prior migrant inflows (Altonji and Card 1991); the placebo instrument replaces information on prior migrant flows with white noise, but gives similar results. This is a consequence of spurious correlation between the instrument and the endogenous variable introduced by applying a common divisor to both (Bazzi and Clemens 2013). The problem is addressed with a specification correction that builds on Kronmal's (1993), after which otherwise identical methods give the same 
results as the original instrumental-variable studies: a positive but statistically insignificant effect on native wages in Israel, a small detrimental and statistically significant effect on native unemployment in France, and an unstable, statistically insignificant effect on native unemployment in Europe.

Overall, we conclude that the evidence from refugee waves reinforces the existing consensus that the impact of immigration on average native-born workers is small, and fails to substantiate claims of large detrimental impacts on workers with less than high school. The paper begins in Section 1 by reviewing discrepant analyses of the Mariel Boatlift in Miami. It proceeds in Section 2 to review discrepant results on the effects of the three other refugee waves. In Section 3 it concludes by discussing the interpretation of this literature.

\section{A refugee wave from Cuba: The Mariel Boatlift}

In mid-1980, a sudden and unexpected influx of refugees from Mariel Bay, Cuba raised the labor supply in Miami, Florida by seven percent. Card (1990) compares trends in Miami to trends in four unaffected control cities and concludes that "the Mariel immigration had essentially no effect on wages or employment outcomes of non-Cuban workers." This study has become influential in labor economics research methods and in immigration policy debate, as well as in graduate economics education (Cahuc et al. 2014).

\subsection{Conflicting reanalyses}

Recent, concurrent reanalyses have reached contrasting conclusions about the robustness of the original Card study. Both Peri and Yasenov (2017) and Borjas (2017) reanalyze the Card result. While Card had studied the effects of the Boatlift on natives with high school or less, both of the new reanalyses study the impact on natives with less than high school. But in this latter subgroup, Borjas finds that the Boatlift caused the wages of males in this subgroup to fall "dramatically, by 10 to 30 percent," while Peri and Yasenov find instead 
"no significant departure between Miami and its control." 2 The studies stress different extracts from the Current Population Survey (CPS), use different weighting variables to construct synthetic control cities, and choose different groups of 'natives' to study. Borjas focuses on non-Hispanic male workers with less than high school, except those under 25 or over 59. Peri and Yasenov (2017) focus on all non-Cuban workers age 19-65 with less than high school. ${ }^{3}$

Several findings in these two conflicting reanalyses have not been adequately explained. We seek to explain them here. These include:

- There is no observed effect on workers with high school or less, or workers with exactly high school. The estimated wage effect of the Mariel Boatlift is indistinguishable from zero for workers with high school or less (Card 1990), and positive for workers with high school only considered separately. ${ }^{4}$ This sharp contrast versus the results for less than high school is somewhat at odds with the fact that the Mariel boatlift created a large positive shock to Miami's supply of workers with high school only and workers with less than high school: Almost half of the Mariel migrants did have a high school degree (Borjas 2017, Table 1). Workers with high school only and less than high school are close substitutes in the U.S. labor market (Card 2009). It is of course possible in principle that the Mariel migrants with less than high school complemented natives with high school only, to a degree that just offset the substitution effect created by Mariel migrants with a high school degree.

- The observed effect size depends on the CPS extract used. Two nationally representative wage survey samples cover the years before and after the Mariel Boatlift: a) the Current Population Survey (CPS) March Supplement, and b) a combination of the CPS May supplement (through 1978) and the CPS Merged Outgoing Rotating

\footnotetext{
${ }^{2}$ Borjas (2017) studies wage effects and does not reanalyze Card's null result on employment effects. Borjas and Monras (2017) do reanalyze Card's null result on employment, and confirm it, as do Peri and Yasenov (2017). An issue faced by all studies is that the CPS did not collect country of birth at this time (pre-1994), so the impact on 'natives' is inferred from estimated impacts on groups likely to be predominantly natives.

${ }^{3}$ In both studies, 'worker' means a person reporting positive annual wage and salary income, positive weeks worked, as well as (in the March CPS) reporting positive usual hours worked weekly, or (in the MORG) positive usual weekly earnings and positive usual hours worked weekly.

${ }^{4}$ The latter finding is below in Figure 2d. The estimated effect is likewise positive for workers with high school or more (Table 13, col. 4).
} 
Groups (MORG) from 1979. Borjas (2017, Tables 5-6) finds effects three times larger in the March CPS data than in the May data. Peri and Yasenov (2017) attribute this large difference to sampling error (the March CPS sample is smaller than the MORG sample) ${ }^{5}$ and recall bias (the March CPS asks about earnings in the prior year, the MORG in the survey week). But because the effect estimated by Borjas (2017) persists across several years, it appears unlikely to arise from pure sampling error or measurement error.

- There is no observed negative effect on U.S. Hispanics. No reanalysis of the Mariel Boatlift finds negative wage impacts for samples that include non-Cuban Hispanics, or for non-Cuban Hispanics separately. ${ }^{6}$ Borjas (2017) argues that omitting U.S. Hispanics is necessary because many U.S. cities were experiencing a contemporaneous influx of non-Cuban Hispanics, but Peri and Yasenov (2017) show that there is no break in the Miami-only wage trend for workers with less than high schoolwhen Hispanics are included - between 1972-1979 and 1980-1990. Though excluding Hispanics is consistent with attempting to study impacts on a predominantly nativeborn sample, the lack of effect on Hispanics is nonetheless a puzzle. Theory does not suggest a clear reason why Cubans would compete directly with non-Hispanic workers while not competing at all with other Hispanics. English language skill is an important segmenter of the labor market (McManus 1990; Peri and Sparber 2009; Lewis 2013), suggesting that newly arrived Cubans could substitute for newly arrived non-Cuban Hispanics at the same low skill level. ${ }^{7}$

- The largest wage effect estimated by Borjas occurs years after the supply shock ends. Peri and Yasenov (2017) observe that after 1984, the share of Cubans among workers with less than high school in Miami returned to pre-Boatlift levels in the CPS data.

\footnotetext{
${ }^{5}$ The March CPS sample is indeed small at 17-27 workers in each year 1977-1983, though the May sample is even smaller (12 and 16 during the 1977-1978 surveys). The annual MORG sample falls in the range 31-56; see Borjas (2017, Table 3).

${ }^{6}$ For our own reanalysis of the Borjas and Monras (2017) results on the Mariel Boatlift for Hispanics only, see subsection 2.4 below. For our reanalysis of low-skill workers including Hispanics, see Figure 2b below.

${ }^{7}$ The finding that the Mariel Cubans strongly substituted for non-Hispanics, but not for Hispanics, contradicts contemporary evidence from nationwide census data. Using 1980 national census data, Borjas $(1987,390)$ finds that Cuban immigrants are complements to black and white natives, as well as to black and white immigrants. He also finds that Hispanic immigrants in general are complements to black natives, concluding that in 1980, "Cubans have not had an adverse impact on the earnings of any of the nativeborn male groups. In fact, a significant complementary relationship exists between Cuban men and white, black, and Asian native-born men."
} 
But the wage effects estimated by Borjas's (2017) method are very large for several years after 1984, peaking in the year 1986 and lasting through the end of the decade. ${ }^{8}$ There may be wage adjustment mechanisms that would lead to such delayed and persistent effects on wages - so that the principal effects of the shock only increase slowly during the supply shock but persist long after it ends - but these mechanisms are unclear.

- There is no observed effect on unemployment. The various studies' disagreement on wage effects of the Boatlift is more striking given their agreement that the Boatlift had no detectable effect on native unemployment (Card 1990; Peri and Yasenov 2017; Borjas and Monras 2017). It is theoretically possible for Cubans flooding the Miami labor market to have large effects on wages but no effects on unemployment, though this would seem to require a high degree of downward flexibility in low-skill wages that is not supported by all strands of the labor literature (e.g. Altonji and Devereux 2000). ${ }^{9}$ Given that the wage effect found by Borjas is so large (in some specifications -0.30 to $-0.45 \log$ points), it is something of a puzzle that the wage and unemployment effects are disjoint.

\subsection{Sensitivity to subgroup selection}

We begin by illustrating the known sensitivity of the recent Mariel Boatlift reanalyses to subgroup selection (Peri and Yasenov 2017, Figure 8). Thereafter we propose a mechanism by which this subgroup selection can generate discordant results.

Figure 1 illustrates the original Card result: there was no fall in low-skill wages in Miami after 1980 relative to pre-trends or control cities. Here we define 'low-skill' as workers with high school or less, the canonical definition in the labor literature. ${ }^{10}$ In the figure,

\footnotetext{
${ }^{8}$ See the discussion of Figure 2f, below.

${ }^{9}$ The higher estimates of the wage impact of the Boatlift would require flexibility in nominal wages, not only in real wages. Cumulative consumer price inflation in Miami from July 1980 to July 1983 was $20.4 \%$. From: U.S. Bureau of Labor Statistics series CUUSA320SA0, "CPI-All Urban Consumers, All items in Miami-Fort Lauderdale, FL, not seasonally adjusted."

${ }^{10}$ Acemoğlu and Autor $(2011,1101)$ describe this definition as "canonical". The early modern immigration literature, as well, used 'low skill' or 'less skilled' as a synonym for workers without specialized training (Johnson 1980), usually taken to mean workers with no college (e.g. Card 1990; Altonji and Card 1991).
} 
all wage averages are normalized so that the 1979 average equals zero. The thick red line shows the annual average wage in Miami for low-skill workers - that is, all non-Cubans age 19-65 with high school or less, who report positive annual wage and salary income, positive weeks worked, and positive usual hours worked weekly, in the March CPS data. The dotted lines show the confidence interval around each year's mean. The dashed line after 1979 shows a linear extrapolation of the Miami trend from 1972 up to and including 1979. The thin, green line shows the annual average wage in the control cities preferred by Borjas (2017). ${ }^{11}$ Miami wages stagnated after 1979, rather than declining as before 1979, and the trend in Miami closely resembled that in the control cities preferred by Borjas from 1979 to 1985.

One might be concerned that the Card analysis obscures wage competition between the Mariel migrants and Miami residents who closely resembled them. Figure 2 shows the same analysis suggests no negative effect of the Boatlift on various subgroups of lowskill Miami workers competing most closely with the Mariel migrants, and even a positive effect on Hispanics. The Mariel migrants were predominantly men, essentially all Hispanic, largely prime-age. They were roughly evenly split between workers with high school only and those with less than high school. Figure 2a shows low-skill workers who are men. Figure 2b shows low-skill workers who are Hispanic. Figure 2c shows low-skill workers who are prime age (25-59). In all cases, there is a large rise (about $+30 \%)$ in Miami wages during 1981-1985 relative to the pre-trend, statistically significant in most years. There is also a large rise (about $+10-20 \%$ ) relative to average wages in the Borjas control cities, statistically significant in some years - albeit statistically insignificant in most years (except Hispanics).

When the subgroup of workers with high school only are analyzed separately (Figure 2d), there is a large and statistically significant rise in wages relative to the pre-trend (about $+30-40 \%)$ and relative to the Borjas control cities (about $+10-20 \%$ ). When the subgroup of low-skill workers with less than high school are analyzed separately, there may be a fall

\footnotetext{
${ }^{11}$ The Card preferred control cities, chosen because they resembled Miami in employment growth "over the late 1970s and early 1980s," are Atlanta, Los Angeles, Houston, and Tampa-St. Petersburg. The Borjas preferred control cities, chosen to resemble pre-1980 employment growth in Miami, are Anaheim, Rochester, Nassau-Suffolk, and San Jose.
} 
(about -10 to $-20 \%$ ) in wages relative to the pre-trend and the Borjas control cities - but it is not statistically precise (both are significant in 1982 only). This closely corresponds to the core result in Peri and Yasenov (2017).

Borjas (2017) reaches a sharply different conclusion by heavily truncating the March CPS data on low-skill workers. The Borjas sample omits women, Hispanics, workers under age 25, workers over age 59, and workers who have finished high school. This leaves an average of 17 observations per year during the period where he finds that largest effect (1983-1987), that is, omitting $91 \%$ of the observations of low-skill workers in Miami during that period (average 185 observations per year). In Borjas's subgroup, there is a large fall in Miami wages (about -30 to $-50 \%$ ) lasting several years after 1980, both relative to the pre-1980 Miami trend and relative to the Borjas control cities (Figure 2f). The peak effect is estimated to occur six years after the Boatlift. Peri and Yasenov (2017) attribute this fall in wages to measurement error arising from the small size of the selected subsample. ${ }^{12}$

\subsection{An explanation for subgroup sensitivity: Sample composition change}

We propose that all substantial disagreement in these prior studies can be explained by previously unreported changes in the underlying survey data. There was a sharp increase in the number of black workers with less than high school sampled by the CPS in Miami, coincident with the Mariel Boatlift but unrelated to it. Because black workers with less than high school earned much less than non-black workers at the same education level, this compositional effect generated a spurious wage decline among Miami workers with less than high school.

Table 1 shows the number of blacks and non-blacks in the CPS samples of Miami workers

\footnotetext{
${ }^{12}$ An important source of measurement error in this setting could arise from 'match bias' in the CPS (Hirsch and Schumacher 2004): Many wage observations in the CPS are imputed from wages earned by a matched 'donor' worker, and the donor can be a worker from a different metropolitan area and ethnicity in both the March CPS and the MORG. In the MORG, the donor can even be a worker from a previous month or previous year. In principle, this could introduce substantial measurement error and attenuate the coefficient estimates, such that the estimated wage effect would rise in absolute value if estimated only on workers with directly observed wages. But the opposite is true in the present case: The core wage effects measured by Borjas (2017, Table 5) decline slightly in absolute value when workers with imputed wages are dropped (results not shown, available on request).
} 
with less than high school used by Borjas (2017): male non-Hispanics age 25-59, in the first three columns. The year is the year of each CPS survey, as in Borjas (2017, Table 3). Between the 1977-1979 surveys and the post-1980 surveys there were large increases in the fraction of black men in the sample, both in the March CPS (upper panel) and the May/ORG CPS extracts (lower panel) - but much larger in the March CPS. In the March CPS, the fraction of black workers roughly tripled between the survey conducted in 1979 and the survey in 1985, rising 55 percentage points (col. 3). The increase in the May/ORG was roughly one third as large. The table shows that no such increase in sampled blacks occurred in the control cities preferred by Card or the control cities preferred by Borjas (cols. 4 and 5). There was also no such increase in sampled blacks for workers in Miami with high school or less, the group analyzed by Card (col. 6).

This compositional change could produce a spurious decline in the average wage of Miami workers with less than high school, for three reasons. The clearest reason is that Miami experienced a large influx of low-income black Haitian workers, precisely in 1980 (Portes and Stepick 1985; Stepick and Portes 1986). Almost all 15,000 of these Haitians had less than high school (Portes and Stepick 1985, 495-497), and about 6,150 were male (41\%, Stepick and Portes 1986, 332). ${ }^{13}$ Before they arrived, there were only 16,940 male black workers with less than high school in Miami in the subpopulation analyzed by Borjas. ${ }^{14}$ Thus the arrival of Haitians in 1980 alone raised the number of blacks in the Borjas subpopulation by up to $36 \%$. The overall compositional change through this channel is likely greater, since Haitians continued to arrive during the early 1980s (Portes and Stepick 1985, 495, fn 3). These Haitian blacks who arrived during 1980-82 cannot be distinguished from U.S. blacks in the data, ${ }^{15}$ and had extremely low incomes. Household income of the newly-arrived Haitians was $\$ 5,521$ per year in 1983 (Portes and Stepick 1985, 497 ), compared to $\$ 17,415$ for the households of otherwise observably identical black men

\footnotetext{
${ }^{13}$ The Haitians who arrived in Miami $1980-82$ had an age distribution similar to that of the Mariel migrants. The Haitians' principal difference was that they had much less educated and were much more likely to originate from rural areas than the Mariel migrants (Portes et al. 1986).

${ }^{14}$ In the 1980 Census 5\% sample microdata (Ruggles et al. 2015), there are 847 observations in the Miami-Hialeah metropolitan area of black male non-Hispanics age 25-59 with less than high school who report positive income and positive weeks worked last year, living in households (pre-1990 definition) rather than group quarters. The sampling weight implies that these observations represent a subpopulation of 16,940 black men in Miami.

${ }^{15}$ Until 1994, the Current Population Survey did not regularly report an individual's country of birth, so U.S. native blacks cannot be distinguished from immigrant blacks in the 1970s and 1980s.
} 
with less than high school in Miami in $1980 .{ }^{16}$

A second reason is the increased coverage of low-skill U.S. black men around 1980 in surveys run by the Census Bureau, who had lower average incomes than non-blacks. Major efforts to raise coverage of blacks, especially males, in nationally representative surveys were spurred by political pressure in the run-up to the 1980 census. In 1978, the Levitan Commission had quantified major undercoverage of black men in the 1970 census (Levitan et al. 1979, 142), raising national pressure to raise coverage of that group in particular. By 1980, Senate hearings described the Census Bureau as "embattled" and engaged in "massive efforts to improve coverage" (U.S. Senate 1981, 1-2, 48). Efforts to respond by improving coverage focused on low-income black men. There was particular pressure in Miami, including a lawsuit led by then-mayor Maurice Ferré who joined leaders of a handful of other cities in alleging large undercounts of low-income urban blacks due to "negligence or malfeasance attributable to local Census Bureau officials."17 The backdrop for these pressures was the the May 1980 riots in the Liberty City and Overtown sections of Miami, which had led to a widespread perception that Miami's low-income blacks had been ignored by the government (Pendleton et al. 1982).

Many of the Levitan Commission's recommendations were implemented immediately in and after 1980 (Hamel and Tucker 1985). These changes included additional 'coverage samples' to capture more low-income black residences and greater efforts by enumerators to identify all of the people residing in a visited residence (Brooks and Bailar 1978). Starting in the March 1981 CPS, the Current Population Survey extracts changed the treatment of race, because "[a]nalysis of results from the 1980 census indicated that reporting of race was not directly comparable with CPS because of different data collection procedures." The degree to which this altered CPS coverage of different black subpopulations is not recorded in publicly available documents, but these measures were taken in order to arrive at "more precise estimates ... for black and non-black populations" (Census Bureau 1982,

\footnotetext{
${ }^{16}$ Again using the 1980 Census 5\% sample microdata (Ruggles et al. 2015), there are 810 reported household incomes in the Miami-Hialeah metropolitan area for the households of black male non-Hispanics age 25-59 with less than high school who report positive income and positive weeks worked last year, living in households (pre-1990 definition) rather than group quarters. The mean of these household incomes, weighted by the household weight, is $\$ 17,415.24$.

${ }^{17}$ Maurice A. Ferré, et al. v. Philip M. Klutznick, et al. C.A. No. 80-2933, Southern District of Florida, October 30, 1980; In Re 1980 Decennial Census Adjustment Litigation., 506 F.Supp. 648 (JPML 1981).
} 
13) - that is, to reduce undercounts of blacks. Because low-skill black men earned less than low-skill non-black men, this would reduce average wages of sampled blacks.

The above reason is reinforced by a third reason: Increases in coverage of low-skill blacks in the surveys tended to include, at the margin, lower-income blacks relative to previously covered blacks. Contemporary efforts to improve coverage among blacks in and after 1980 clearly focused on the poorest blacks (Levitan et al. 1979, 139; U.S. Senate 1981, 8283; Durant and Jack 1993). Ethnographers at the time found that marginal blacks added through more extensive survey efforts tended to be the poorest blacks - those who had been concealed from surveyors in order to preserve welfare benefits, or those whose "transiency and mobility" in the poorest inner-city black neighborhoods "does not fit the Census Bureau assumption of a "usual residence"" (Hainer et al. 1988, 514). Indirect evidence for negative selection of this kind is that within sampled workers with less than high school, years of education fell in Miami after 1980 relative to the control cities (Appendix Table 1). ${ }^{18}$

\subsection{Testing for spurious wage effects}

Figure 3a illustrates how this compositional change in the samples coincides closely with large changes in the average wage of workers with less than high school. The figure plots the annual average wage, for Miami workers in the Borjas sample, against the fraction of the sample that is black in each year. ${ }^{19}$ There is a very strong, negative association between the black fraction and the average income. The line in the figure shows a simple least-squares fit through all the datapoints. The doubling of the black fraction between the pre-Boatlift years and the post-Boatlift years is associated with roughly a $40 \%$ decline in the average wage (the log weekly wage falls from about 5.6 to 5.1 , that is, from $\$ 270$

\footnotetext{
${ }^{18}$ Another mechanism that could spuriously produce wage declines in Miami at this time, in principle, would be a suddenly influx of U.S. blacks into the city coincidentally occurring in 1980. But tabulations by the Census Bureau show no important change to the rate of increase of Miami's overall population of U.S. blacks (at all skill levels) in the years after 1980 relative to the years before 1980 (data from the full census 1960-80 in Bureau of the Census 1982, 22; data from the CPS 1980-85 in Starsinic and Forstall 1989, 40-41). And histories of Miami's black population mention no large and sudden surge in overall native-born black migration to Miami in 1980 that would cause a discontinuity in the true population of native-born blacks there (Dunn 1997).

${ }^{19}$ In Table 1 above - following Borjas (2017, Table 3) - the "Survey Year" is the year in which the survey was conducted. Here, in Figure 3, the "Earnings Year" is the year in which reported earnings in the March CPS were earned: the year prior to the survey year - following Borjas (2017, Table 5). The reason for this difference is that the March CPS asks workers about their earnings in the preceding year.
} 
to $\$ 164)$. We interpret this association as largely a causal relationship, since it is not plausibly conincidental. The change in the black fraction of the sample could not be a compositional effect of the Boatlift itself, since all of these samples omit Hispanic blacks.

Figure $3 \mathrm{~b}$ shows that for Miami workers with exactly high school there is a very similar negative relation between the wage and the share black. Yet there is no fall over time in the average wage because the share black is not increasing over time.

Figure 3c returns to the Borjas subpopulation of workers with less than high school, and tests for compositional change for samples of those workers in the control cities preferred by Borjas. Also among these workers, there was neither a substantial change in the race composition of the samples around 1980 nor a substantial fall in the wage, despite a relationship between share black and the wage that is similar to Miami's. It likewise suggests that if a large change in the race composition of the samples in the control cities had occurred, it would have produced a large fall in the average wage. But no such change occurred in the control cities, as shown in the figure and in Table 1. In all three panels of the figure, the least-squares fit line shows a negative relationship between the fraction black and the average wage. But only in panel (a) does the fraction black jump between the pre- and post-Boatlift years (from $40-50 \%$ to $70-80 \%$ ), and only in that panel does the wage drastically fall (by about $0.5 \log$ points).

This evidence suggests that the wage effects of the Mariel Boatlift estimated by Borjas (2017) are severely biased, and that a substantial portion of those estimates is spurious. The most straightforward approach to estimating the degree of the bias is to adapt the analysis to adjust for the share of blacks and compare with the original results. Borjas's (Table 5) core results begin with yearly individual-level regressions (for workers of all education levels in Miami and the control cities) that adjust wages for age and city, and then average the adjusted wages for workers with less than high school by city and year. He then performs differences-in-differences regressions at the city-year level, dropping 1980 earnings because in both CPS extracts 1980 is a mix of pre- and post-Boatlift data. The covariates are the interactions of a dummy for Miami and dummies for three-year time periods: their coefficients would ideally be zero for years before the Boatlift (indicating 
that the controls were similar to Miami), while their coefficients for years after the Boatlift indicate any effect of the Boatlift. Because the city-year averages are pre-adjusted by city and year, the resulting regressions run by Borjas test not for a difference-in-difference of the average wage level, as Borjas incorrectly states, but instead for a difference-in-difference of the relative wage of workers with less than high school (compared to the average worker at any other education level).

We adapt this procedure to include controls for black in the individual-level regressions. Table 2a shows the results for the March CPS data. The first two columns are an exact replication of the corresponding columns of Borjas (2017, Table 5), with very large estimated treatment effects on wages relative to both the Card and Borjas control cities. In columns 3 and 4, prior to averaging within city-period cells, the wage of each individual is adjusted using a black indicator variable whose coefficient is constrained to take the same value for all cities, education levels, and ages, but is unique for each year. This change reduces the magnitude of the treatment effect by roughly one third.

It is a strong assumption to constrain the black indicator coefficient to be identical for all cities and skill levels. Empirically, the black-nonblack wage gap does vary by city and skill level. Theoretically, there are important reasons why the black-nonblack wage gap would be different in Miami than in the control cities. In the 1980s, blacks constitute over two thirds of Miami's non-Hispanic males with less than high school, but less than $10 \%$ of the same group in the Borjas control cities (Table 1). Cities with sharply different populations of low-skill blacks exhibit different patterns of geographic and occupational segregation that can shape the black-nonblack wage gap. Thus, in columns 5 and 6 of Table 2 a, the coefficient on the black indicator is allowed to take unique values for each city, but is still constrained to take the same value for all education levels. The treatment effect is more heavily attentuated - by more than half of its original value - and is no longer statistically significant relative to the control cities preferred by Card.

In columns 7 and 8 , the coefficient on the black indicator is allowed to take unique values for workers with less than high school in each city. The coefficient estimates in these columns therefore represent the effect on non-blacks with less than high school. The estimates 
in these columns have the disadvantage of controlling away any additional effect that the Mariel Boatlift might have had on the wages of blacks with less than high school compared to non-blacks, but have the advantage that they would not be affected by changes in the racial composition of the subsample with less than high school. In these columns the wage effects are neither economically nor statistically significant.

Table $2 \mathrm{~b}$ repeats the above analysis using the May/ORG CPS extract - in which larger samples represent the same population. In these data, when we control for a black indicator that is specific to each city, but identical across education levels (columns 5 and 6), there is no statistically significant treatment effect relative to either the Card or Borjas control cities. The same is true when the city-specific black indicator is allowed to take a unique coefficient for workers with less than high school (columns 7 and 8).

The most direct way to test for wage effects in the absence of an increase in low-income blacks in the sample, in principle, would be to simply repeat the analysis dropping blacks from the sample. But the already small size of the samples makes this impossible in practice. Figure 4 modifies Figure $2 \mathrm{f}$ to show average wages for non-blacks only, in the March CPS extract. Extremely few observations remain: an average of only four observations per year in the years where Borjas finds the largest treatment effect (1983-1987, see Table 1). At this point, over $98 \%$ of the original sample of low-skill workers has been discarded, and statistical noise prevents any conclusion about Miami wage trends.

In sum, the core regressions of Borjas (2017) are fragile when adjusted to control for a city-specific black indicator. When this is done, there is only a statistically significant wage effect in the March CPS extract but not the May/ORG, and even in the March extract, the significance of the effect depends critically on the choice of control cities. When the city-specific black indicator is allowed to vary by education group, there is no significant treatment effect at all. This suggests that the degree of bias in the original Borjas (2017) result is high. The analysis cannot be carried out separately for the subsample of blacks because that subsample is greatly contaminated by simultaneous, unrelated compositional change, and the analysis cannot be carried out separately for non-blacks because minuscule sample sizes prevent it. Overall, the evidence is compatible with a model in which the 
Mariel Boatlift caused a modest fall in the wages of this subpopulation of roughly $-2 \%$ to $-8 \%$ in the few years immediately after the Boatlift, but it is also compatible with a model in which this effect was zero. ${ }^{20}$

\subsection{Reconciliation of prior findings}

Prior studies of the Mariel Boatlift emphasize different subgroups. Card (1990) focuses on workers with high school or less. Borjas (2017) focuses on a small subset of those workers, non-Hispanic men with less than high school, except those under 25 or over 59 . Peri and Yasenov (2017) focus on all non-Cubans with less than high school. Their sharply different results can be explained by large contemporaneous changes in the composition of the small subsample used by Borjas (2017), changes that were not substantial in the larger subsamples used by Card (1990) and by Peri and Yasenov (2017).

This can also explain several other features of these previous findings. 1) It can explain why Borjas (2017) and Peri and Yasenov (2017) find a wage effect roughly three times larger in the March CPS than in the May/ORG extract: The change in racial composition is about three times larger in the March CPS than in the May/ORG extract (Table 1). 2) It can explain why all prior studies find no effect of the Mariel Boatlift on unemployment: There was no difference between black and nonblack unemployment rates among male nonHispanic less-than-high-school workers in Miami, despite the large difference between black and non-black wages there (Table 3), so a change in racial composition would not change average unemployment in the sample. 3) It can explain why the wage effects estimated by Borjas (2017) persist into the period 1985-1988, by which time the supply shock of Cubans had subsided. The shift in racial composition of the sample continues - and in fact increases - through the years 1985-1988. 4) It can explain why Borjas (2017) finds larger effects in his preferred control cities than in Card's (1990) preferred control cities: Coverage of blacks fell in the Borjas control cities, even hitting zero in 1983, but did not fall in the Card control cities.

\footnotetext{
${ }^{20}$ The coefficient estimate in Table 2 a column 8 , row $1981-83$ is $-8 \%$. This is the most negative coefficient estimate in columns 7 or 8 in either Table $2 \mathrm{a}$ or Table $2 \mathrm{~b}$. The corresponding coefficient in Table $2 \mathrm{~b}$ is $-2 \%$. Several of the coefficient estimates in columns 7 and 8 of both tables are positive. None of the coefficients is statistically signficant.
} 


\section{Comparing the Mariel Boatlift to other refugee waves in Israel, France, and across Europe}

Recent reanalysis has also challenged earlier results on the labor market impacts of three other large refugee waves - in France (Hunt 1992), Israel (Friedberg 2001), and across Europe (Angrist and Kugler 2003) — alongside the Mariel Boatlift in a parallel instrumentalvariables framework. For all four of these cases, Borjas and Monras (2017) seek to improve on causal identification in the original studies with an instrumental variable closely related to the instrument introduced by Altonji and Card (1991). They run a series of regressions of the form

$$
\Delta \log w_{r s}=\theta_{r}+\theta_{s}+\eta m_{r s}+\varepsilon_{r s}
$$

where $w_{r s}$ is the wage or other labor market outcome for native workers with skill $s$ in region $r ; \theta_{r}$ and $\theta_{s}$ are region and skill fixed effects; $L_{r s t}$ is the native population with skill $s$ in region $r$ at time $t, m_{r s} \equiv \frac{M_{r s 1}}{L_{r s 1}}$ is the size of the refugee supply shock relative to the native population of skill $s$ in region $r$ at time 1; time 1 is after the refugee influx, time 0 is before it; the coefficient $\eta$ is to be estimated and $\varepsilon$ is an error term. In one of the reanalyses, $r$ indexes occupations rather than geographic areas. ${ }^{21}$ Because refugees' choice of geographic destination can be endogenous, the authors instrument for the refugee shock $\frac{M_{r s 1}}{L_{r s 1}}$ with prior migration to that region $\frac{M_{r s 0}}{L_{r s 0}}$, resting on the idea that previous migrants attract new migrants to the same area (following Altonji and Card 1991).

A potential weakness of this instrumental variables approach lies in the fact that the native population of each region changes little over the short time periods in question, thus both the instrument and the endogenous variable have a common divisor $\left(L_{r s 1} \approx L_{r s 0}\right)$. This can generate spurious correlation between the ratios $m_{r s 1}$ and $m_{r s 0}$ regardless of the numerator, as first observed by Pearson (1896). In the colorful example of Neyman (1952,

\footnotetext{
${ }^{21}$ This specification varies between the reanalyses. In the France reanalysis, for example, location fixed effects $\theta_{r}$ are omitted (see discussion in subsection 2.2). The reason given for omitting these fixed effects in the France reanalysis is that including them affects the results: it "makes the coefficients for the French repatriates supply shock very unstable" (Borjas and Monras 2017, 44). Also in the France reanalysis, the labor market outcome is employment but not wage (wage is unavailable in the original data); but in the Israel reanalysis it is wage but not employment. In the Israel reanalysis the index $r$ is across occupations rather than regions, due to Israel's small geographic extent. Alternative forms of all regressions are run controlling as well for the term $\eta \log \frac{L_{r s 1}}{L_{r s 0}}$, motivated by theory, but all results are substantively unaffected.
} 
143), one could conclude that storks bring babies by correlating storks-per-woman with babies-per-woman across any set of geographic areas. The variables would correlate well by construction, due to their common divisor. ${ }^{22}$

This problem, highlighted more recently by Kronmal (1993), affects instrumental variables as well as standard regression analysis (Bazzi and Clemens 2013). One would find storksper-woman to be a strong instrument for babies-per-woman even if storks are irrelevant to babies, and could use that framework to show spuriously that babies cause any regional outcome that is correlated with the number of women in the region.

The problem can be most simply revealed by taking an instrumental variable regression of this type with an economically meaningful variable in the numerator of the instrument, and replacing that numerator with storks - or any other irrelevant placebo. Robustness to such a change is a telltale indicator of a spurious result in the original instrumental variables regression, one form of what has been called the "blunt instruments" problem (Bazzi and Clemens 2013). Robustness to this placebo substitution does not invalidate the result, but demonstrates that the result requires further scrutiny to demonstrate that the original instrument contains identifying information beyond variance in the denominator (which may not be a valid instrument by itself). A recent and more general literature suggests that instrumental variable results in practical application are often spurious, with between a third and half of instrumental variable results published in leading journals falsely rejecting the null due to their treatment of standard errors (Young 2017).

Kronmal (1993) proposes a specification correction for this problem in an Ordinary Least Squares setting that we here adapt to the instrumental variables setting. The robustness test he proposes is to simply split the ratio variable into two separate variables, while accounting for the nonlinear relationship between numerator and denominator. ${ }^{23}$ In the stork example, a regression of $\log \left(\frac{\text { babies }}{\text { woman }}\right)$ on $\log \left(\frac{\text { storks }}{\text { woman }}\right)$ will give a spurious coefficient, but a regression of $\log$ (babies) on both $\log$ (storks) and $\log$ (women) will give the correct

\footnotetext{
${ }^{22}$ See also inter alia Pendleton et al. (1979, 1983); Jackson and Somers (1991); Wiseman (2009).

${ }^{23}$ Kronmal considers a simple ratio and proposes controlling for the reciprocal of the denominator. In the present case the ratio is logged, so the equivalent is to control for the log of the denominator (which is equivalent to controlling for the log of the reciprocal of the denominator).
} 
positive coefficient on women and the correct null coefficient on storks. We modify that correction in one way: Because here the refugee shock variable frequently takes value zero, the $\log$ transformation would truncate those observations, so we instead use the inverse hyperbolic sine transformation. ${ }^{24}$

We therefore modify the regression (1) with the Kronmal correction to

$$
\Delta \log w_{r s}=\theta_{r}+\theta_{s}+\eta\left(\operatorname{asinh} M_{r s 1}\right)+\eta^{\prime}\left(\operatorname{asinh} L_{r s 1}\right)+\varepsilon_{r s},
$$

where asinh is the inverse hyperbolic sine and where the endogenous refugee supply shock $\left(\operatorname{asinh} M_{r s 1}\right)$ is instrumented by the predetermined stock of prior migrants $\left(\operatorname{asinh} M_{r s 0}\right){ }^{25}$

\subsection{Israel reanalysis}

Friedberg (2001) studies a large and sudden influx of Soviet refugees to Israel between 1990 and 1994, large enough to raise Israel's population by $12 \%$. She uses information on migrants' former occupations in their home countries to construct an instrument for the occupations they take in Israel, and finds "no adverse impact of immigration on native outcomes" within occupations. Borjas and Monras (2017) reanalyze the episode using instead the Altonji and Card instrument based on prior migration flows into educationoccupation cells inside Israel, and instead find large detrimental effects of the migration on Israel natives' wages.

Table 4 carries out the placebo test described above on the Borjas and Monras application of the prior-flows instrument to the Israel refugee wave. First, we construct a placebo instrument that contains no information about prior flows of migrants into the educationby-occupation cells in the reanalysis. We take the pre-influx Soviet immigrant stock across occupations, by skill group - and generate Poisson-distributed white noise with the same

\footnotetext{
${ }^{24}$ Regression coefficients on variables transformed with the inverse hyperbolic sine can be interpreted identically to those using the traditional log transformation (as approximating percent changes) since $\frac{d}{d x} \operatorname{asinh} x=\frac{1}{\sqrt{1+x^{2}}} \approx 1 / x=\frac{d}{d x} \ln x, \forall x \gtrsim 2$. But unlike the log transformation, the inverse hyperbolic sine has desirable properties near zero and is defined at zero ( $\operatorname{asinh} 0=0)$. See Burbidge et al. (1988); MacKinnon and Magee (1990).

${ }^{25}$ Note again that in this Israel case only, subscript $r$ indexes occupations rather than regions.
} 
mean as the real numerator $M_{r s 0}$. The means of these placebo numerators $\tilde{M}_{r s 0}$ for each skill group are shown in Table 4a. We then construct a placebo instrument by dividing that white-noise numerator $\widetilde{M}_{r s 0}$ by the same divisor as the true instrument $\left(L_{r s 0}\right)$. The resulting placebo instrument $\tilde{m}_{r s}$ contains no information about prior migration flows.

Second, we replicate the Borjas and Monras (2017, Table 1, cols.1, 3) reanalysis of the Israel case. In Table 4b, columns 1 and 3, we exactly replicate Borjas and Monras's (2017) findings with their original instrument. Third, we replace the Borjas and Monras instrument with our placebo instrument. Columns 2 and 4 use the placebo instrument, without changing anything else in the analysis. The placebo instrument achieves a result that is similar - and actually increases in magnitude and statistical significance. In both columns the estimated detrimental effect of Soviet migrants on native wages is a bit larger in absolute value than in the original study; in column 2 the result is more statistically significant than in the original. ${ }^{26}$

Identification of the effect of the refugee shock ostensibly rests on the distribution of prior migration across occupations within skill cells. But when all information about prior migration is purged from the instrument, the result stands, and in fact grows stronger. This suggests that the original result could be spurious, driven by irrelevant relationships between wage trends for natives in different skill cells and the population size of those cells (the denominator of the instrument).

We apply the Kronmal specification correction to the instrumental variables regressions, splitting the refugee shock numerator and the population size into two separate variables in the second stage. Then the absolute magnitude of the refugee shock (in number of people) can be strongly and validly instrumented with the absolute magnitude of lagged migration to the region or occupation in question.

\footnotetext{
${ }^{26}$ Instrumentation is not as strong using the placebo instrument. But the degree of potential bias from weak instrumentation is around $25 \%$ of the coefficient estimate (Stock et al. 2005) -in the absence of which the placebo coefficient would match the original coefficient even more closely. Furthermore the Anderson-Rubin (1949) F-test for the significance of the refugee shock in the second stage, a test that is robust to weak instrumentation, rejects the hypothesis that the coefficient is zero at the $5 \%$ level in column 2.
} 
Table 5 shows that the second-stage coefficient on the émigré supply shock is statistically indistinguishable from zero under the Kronmal correction. The first column of the table precisely replicates the original result in Borjas and Monras (2017, Table 6). The second column shows that the result is nearly identical when the ratio measure of the supply shock undergoes the inverse hyperbolic sine transformation. The third column shows regression (2), in which the current migration shock is instrumented with true lagged migration into the cell. The coefficient on the refugee supply shock becomes indistinguishable from zero, and its magnitude - adjusted to be comparable to column 1 (in square brackets) - falls in absolute value from -0.616 to $-0.284 .^{27}$ Instrumentation remains very strong in column 3, with a Kleibergen-Paap (2006) F statistic over 14, but the weak-instrument robust Anderson-Rubin (1949) F-test fails by a wide margin to reject the hypothesis that the second-stage coefficient on the refugee shock is zero. ${ }^{28}$

The last column of Table 5 offers an explanation for this pattern, by simply regressing the absolute magnitude of the refugee supply shock $\left(\operatorname{asinh} M_{r s 1}\right)$ on the absolute magnitude of the population in each cell $\left(\operatorname{asinh} L_{r s 1}\right)$. The coefficient of 1.15 is indistinguishable from unity, and $72 \%$ of the variance in the size of the refugee supply shock is explained simply by the size of the native population in each education-occupation cell. That is, most of the information contained in the size of the refugee supply shock is contained in the size of the native population in each cell; the denominator of the original instrument contains almost all information about prior flows. Thus any coincidental relationship between wage trends in some occupation-skill cells and the absolute size of that cell could produce a second-stage coefficient that rejects the null of zero. When this possibility is eliminated by the Kronmal correction, in column 3 of Table 5, the second stage coefficient cannot be distinguished from zero.

Of course the original instrument used by Friedberg (2001), also constructed from a ratio, could be vulnerable to the same problem. Thus in Tables 6 and 7 we repeat the placebo

\footnotetext{
${ }^{27}$ This is done, here and in the tables to follow, by multiplying the Kronmal coefficient by $\frac{1-p}{p}$, where $p$ is the immigrant share: here $-0.0348 \cdot \frac{1-0.109}{0.109}=-0.284$. See Appendix $\mathrm{C}$ for proof. The results are substantively unchanged when controlling for $\log \frac{L_{r s 1}}{L_{r s 0}}$, as Borjas and Monras (2017) do in some specifications.

${ }^{28}$ This is the proper test for the present just-identified setting of one endogenous variable and a single instrument.
} 
test and Kronmal correction for Friedberg's original result. Friedberg's instrument is not the lagged ratio in Israel of Soviet émigrés in each skill-occupation cell per Israeli in that cell used by Borjas and Monras, but rather the number of émigrés in each skill-occupation cell prior to migration, in their home countries, per lagged Israeli in that cell in Israel. Table 6a shows the means, by education group, of the Poisson-distributed white noise generated to replace the numerator of the instrument.

In Table 6b, column 1 we then exactly replicate Friedberg's core instrumental variable result, a positive impact on native wages that is statistically significant at the $5 \%$ level. Column 2 shows that Friedberg's result, unlike Borjas and Monras's, cannot be reproduced with the placebo instrument. The second-stage coefficient now fails to reject a wide range of negative and positive effects on wages. The weak-instrument robust Anderson-Rubin $F$-test fails by a wide margin to reject the hypothesis that the second-stage coefficient is zero. This implies that the original instrumental variable used by Friedberg contained identifying information in the numerator, as intended.

Thus we do not expect the Kronmal specification correction to greatly alter Friedberg's core result, and this is indeed what we observe in Table 7. There, as in Table 5, the first column replicates the original result and the second shows that it is unchanged under the inverse hyperbolic sine transformation of the immigration shock ratio. The third column splits that ratio into its numerator and denominator (each in inverse hyperbolic sine transformation, asinh), instrumenting for the numerator only (asinh of the 1994 Soviet émigré stock in Israel in each cell) with the asinh of the pre-migration size of that cell given the migrants' previous occupations in their home countries (the numerator of the Friedberg instrument). The second-stage coefficient remains positive but is no longer statistically significant - though the weak-instrument robust Anderson-Rubin F-test does reject at the $11 \%$ level the hypothesis that the second-stage coefficient on the endogenous migrant shock is zero. The magnitude of the coefficient estimate in column 3, adjusted to be comparable with column 1 (in square brackets), is $0.572 .^{29}$

This departs slightly from Friedberg's original finding that any zero or negative wage

${ }^{29}$ This is calculated, as above, by: $0.0780 \cdot \frac{1-0.12}{0.12}=0.572$. 
impact could be rejected at the $5 \%$ level. But it does remain in accordance with Friedberg's (2001, 1403) interpretation of that finding: "we cannot reject the hypothesis that the mass migration of Russians to Israel did not affect the earnings or employment of native Israelis."

\subsection{France reanalysis}

Hunt (1992) studies the effects on French wages and native unemployment of the arrival from Algeria in 1962 of 900,000 people of European (and Jewish) origin (e.g. Festy 1970; Guillon 1974). Algeria's independence in that year led almost the entire population of European origin to flee to France, along with about 140,000 Muslims of Arab and Berber origin (Roux 1991, 230), mostly illiterate "Harkis" who faced reprisals for having fought for France in the war of independence. Using variation by department (province) and time, she finds that the arrival of the repatriates raised French native unemployment by "at most 0.3 percentage points." This result stems from the fact that the repatriates represented $1.6 \%$ of the 1968 labor force and that Hunt finds a one percentage point increase in repatriates in the labor force increased the unemployment rate by 0.19 percentage point; to a very close approximation 0.19 is also the effect of an increase in the labor force of one percent due to the repatriates (see Appendix C). Hunt does not study the effect of the Harkis.

Using variation across region (each containing several departments), education and time, along with the prior-flows instrumental variable strategy, Borjas and Monras (2017) reanalyze the impact of the repatriates and attempt to analyze for the first time the effect of the Harkis. While Hunt had access to data only at the department level, Borjas and Monras $(2017,5)$ use individual-level data. They find that a one percent increase in population due to repatriates raised the unemployment rate of similarly educated male natives by a statistically significant 0.09 percentage point (Borjas and Monras Table 10, cols. 3 and 4). Although the effect estimated is conceptually slightly different (see Appendix C), it seems reasonable to consider this result to be similar to Hunt's, given standard errors, suggesting Borjas and Monras's exclusion of native women may be innocuous. ${ }^{30}$

\footnotetext{
${ }^{30}$ This similarity may be coincidental, however, since the data used by Borjas and Monras identify neither the repatriates nor the Harkis. Repatriates are imputed from the data rather than indicated in the data. The authors' imputation identifies 1.4 million repatriates, more than $50 \%$ too many, with their sample including more than half the Harkis - the 84,000 who had acquired French nationality by 1968 (Roux 1991, 226) — and non-repatriate French nationals returning from residence abroad.
} 
Borjas and Monras also find that a one percent increase in the population due to the arrival of Algerian nationals raised the unemployment rate of similarly educated male natives by a statistically significant 0.25 percentage point (Borjas and Monras Table 10 columns 3 and 4). This is almost three times the effect they find for the imputed repatriates, though similar in magnitude to the Hunt estimate of the impact of the repatriates (0.19), given standard errors. This similarity is obscured in the discussion in Borjas and Monras, as the magnitude the authors emphasize is the product of the 0.25 coefficient and the share of Algerians in the lowest education group in the most affected cities, a much larger number. Probably only half the authors' sample of 160,000 Algerians are actually Harkis, since they count 84,000 Harkis as repatriates, with the remainder being economic migrants from Algeria. ${ }^{31}$

The estimated effects thus do not differ statistically significantly between Hunt (1992) and Borjas and Monras, nor are the differences in the point estimates very large. Nevertheless, we scrutinize the use of lagged migration as an instrument in both papers, beginning with Borjas and Monras. We first repeat the reanalysis of subsection 2.1, above, focusing on the Algerian nationals. In Table $8 \mathrm{a}$ we show the means of Poisson-distributed white noise $\widetilde{M}_{r s 0}$ with the same mean as the prior stocks of Algerian migrants $M_{r s 0}$ across French regions within skill cells. Table $8 \mathrm{~b}$ shows that the detrimental effects estimated for natives are larger using the placebo instrument $\tilde{m}_{r s 0}$, as in the Israel case. The first column exactly replicates the core result in Borjas and Monras Table 10: IV coefficients of 0.09 for the repatriates and 0.25 for the Algerians. In the second column, we replace the true Algerian prior stock instrument with the placebo: the coefficient estimate rises to 0.42 and retains high statistical significance. ${ }^{32}$

In column 3, we drop the French-citizen repatriate shock from the original regression in column 1, showing that the coefficient estimate on the Algerian national shock is essentially unchanged at 0.28 . In column 4 , we then replace the true Algerian prior migrant stock instrument with the placebo instrument. Again the coefficient estimate retains high

\footnotetext{
${ }^{31}$ Economic migrants are described by e.g. Roux (1991, 255).

${ }^{32}$ The standard error on the placebo instrument of column 2 is much higher than in the Borjas and Monras original, but the weak instrument-robust Anderson-Rubin F-test strongly rejects the hypothesis that the second-stage coefficient is zero.
} 
statistical significance, rising in magnitude to 0.44 , with instrumentation stronger than in column 2 (the Kleibergen-Paap $F$-statistic rises to 5.3). Column 5 shows that this result is unaltered by controlling for the interperiod change in the native population (following Borjas and Monras). As in the case of Russian migration to Israel, therefore, the strategy for identifying the causal relationship between the refugee inflow and native labor market outcomes is potentially flawed.

In Table 9, we carry out the Kronmal specification correction using equation (2) just as was done for Israel above. The first column precisely replicates the core result using the original analytic methods for Algerian nationals in isolation (Table 8b, column 3). Column 2 shows that this finding is identical when the ratio measure of the migrant shock (and its instrument) undergo the inverse hyperbolic sine transformation. Column 3 shows that under the Kronmal specification correction, with strong instrumentation (a Kleibergen-Paap F-statistic of 42), the coefficient on the Algerian shock is still positive and statistically significant, with a magnitude of 0.0023 . Column 4 then controls for the concurrent repatriate shock, instrumented by the lagged repatriate stock: this is the Kronmal-corrected equivalent of Table 8b, column 1. The coefficient on the Algerian shock is positive and statistically significant but falls to 0.0018 ; this implies that a one percent increase in the population due to the Algerians raised unemployment by about 0.23 percentage point. ${ }^{33}$ In square brackets we convert this to a value comparable to the Borjas and Monras coefficient: if Algerians increase the population by one percent, unemployment rises 0.23 percentage point. ${ }^{34}$ The adjusted coefficient for repatriates is also similar to the Borjas and Monras specification estimate of 0.04.

There is thus general agreement between all of the findings considered: the original results of Hunt, the reanalysis of Borjas and Monras, and the results with the specification correction. For the Algerian-national shock, not studied by Hunt, both Borjas and Monras and Table 9 here imply that if Algerians increase the population by one percent, unemployment rises by $0.23-0.24$ percentage point. For the French-national repatriate shock, Hunt's

\footnotetext{
${ }^{33}$ As above, this is calculated as $0.00182 \cdot \frac{1-0.008}{0.008}=0.226$.

${ }^{34}$ In the last column, we regress the absolute magnitude of the Algerian supply shock (asinh $\left.M_{r s 1}\right)$ on the absolute magnitude of the population in each cell $\left(\operatorname{asinh} L_{r s 1}\right)$. $81 \%$ of the variance in the refugee shock is explained by the size of the cell.
} 
findings cannot be statistically distinguished from Borjas and Monras's finding that a one percent increase in population due to repatriates raised native unemployment by 0.09 percentage point, though this result is not robust to the inclusion of the same regional fixed effects used in the other reanalyses, and the result is not statistically significant in the Kronmal-corrected specification used here.

Hunt also uses a potentially problematic instrument: the share of early (1954-1962) repatriates as a share of the population, used to instrument 1962-1968 repatriates as a share of the labor force. Like the original instrument used in Friedberg's study of Israel, this ratio instrument could be subject to the same problems considered above. However, in addition to this instrument, Hunt uses the department average temperature: repatriates tended to settle in southern France where the climate was more similar to that of Algeria. We reproduce Hunt's main unemployment coefficient of 0.195 (Hunt Table 3 column 4) in our Table 10 column 1. ${ }^{35}$ An obvious robustness check is simply to drop the lagged migration instrument and instrument with temperature alone: this is shown in our column 2 . The coefficient drops to 0.120 with a slightly larger standard error, which renders the coefficient statistically insignificant. Nevertheless, we can rule out that a percentage point increase in repatriate's share in the population increases unemployment by more than 0.31 percentage point. To render the coefficient comparable to the Borjas and Monras coefficient an adjustment is necessary (multiplying the coefficient by one minus the share of repatriates), an almost identical value shown in square brackets in column 2 .

Instead of dropping the lagged migration instrument, we can instead drop the temperature instrument so as to pursue comparisons with Borjas and Monras. Column 3 shows that the coefficient of 0.209 is similar to Hunt's original coefficient of 0.195 . In column 4 , we take the inverse hyperbolic sine of both the repatriate share and its instrument, and obtain the same result as in column 3. In column 4, we control separately for the inverse hyperbolic sine of the 1968 number of repatriates and the 1968 labor force, instrumenting the former with the inverse hyperbolic sine of the 1962 number of repatriates. The coefficient of interest is a statistically significant 0.00254. Thus, as shown in square brackets, if repatriates increase the size of the labor force by one percent, the unemployment rate

\footnotetext{
${ }^{35}$ This uses robust standard errors, which Hunt did not.
} 
increases by 0.16 percentage point. This Kronmal-corrected specification using the lagged migration instrument thus yields a point estimate very similar to the point estimate using temperature as an instrument in column 2, a slightly smaller effect than found by Hunt or by Borjas and Monras. The estimates are all statistically similar, however, given standard errors. $^{36}$

\subsection{Europe reanalysis}

Angrist and Kugler (2003) study the effects of an influx of refugees from the Balkan War on 18 European countries during the 1990s. They find that a sudden increase in the migrant stock of one percentage point raises native unemployment by 0.83 percentage point. Borjas and Monras (2017) reanalyze the episode in seven of those European countries (Austria, Greece, Ireland, Portugal, Romania, Spain, and Switzerland), again using the prior-migration instrument. They likewise find a detrimental effect on native unemployment, though much smaller in magnitude: an increase in the migrant stock of one percentage point raises native unemployment by 0.49 percentage points. This is larger than the effect found for France.

In this case there is little disagreement between the original study by Angrist and Kugler (2003) and the reanalysis by Borjas and Monras (2017). Both find that the refugee wave they study substantially displaced natives in the labor market, though estimates in both are statistically imprecise. Angrist and Kugler (2003, F328) warn of identification problems and statistical imprecision in their instrumental variables estimates and recommend interpreting those estimates as an upper bound on the true effect. The instrumental variable estimates of Borjas and Monras (2017) for unemployment are statistically insignificant even at the $10 \%$ level.

Nevertheless, we proceed with the same placebo test as above to test the robustness of these findings. Table 11a shows the means of the placebo numerator $\tilde{M}_{r s 0}$ by country. Table 11b replicates the core result in Borjas and Monras (2017, Table 13), and then

\footnotetext{
${ }^{36}$ In column 6, we regress the transformed number of $1962-1968$ repatriates $\left(\operatorname{asinh} M_{r s 1}\right)$ on the transformed number in the labor force $\left(\operatorname{asinh} L_{r s 1}\right)$. $80 \%$ of the variance in the refugee shock is explained by the size of the department labor force.
} 
reproduces it using the placebo instrument $\tilde{m}_{r s 0}$. As in the Israel and France cases above, the result strengthens when the placebo is used: the coefficient estimate rises somewhat, and it is statistically significant at the $10 \%$ level in column 2 (unlike the estimate in the original).

Table 12 carries out the Kronmal correction as above. Column 1 replicates the original result, column 2 shows that it is identical under the inverse hyperbolic sine transformation, and column 3 carries out the Kronmal correction instrumenting with the lagged migrant stock. The coefficient estimate is negative and statistically insignificant, with a magnitude (adjusted in square brackets, as above, to be comparable to the column 1 coefficient) of $-0.26{ }^{37}$ Instrumentation is quite weak, with a Kleibergen-Paap $F$ statistic of just 1.5. However the weak instrument-robust Anderson-Rubin (1949) F-test strongly rejects the hypothesis that the second-stage coefficient is zero - suggesting that some information is indeed contained in the negative second-state coefficient, and failing to show that the Balkan supply shock raised unemployment in refugees' destination regions.

This result is discordant with Angrist and Kugler, but only to a limited degree. Their OLS regressions find a "small" but statistically significant detrimental effect of Balkan refugees on native unemployment, but their instrumental variables estimates are mostly statistically insignificant and exhibit a fragility that, the authors find, "suggests these estimates are probably driven by forces other than increased immigration" (Angrist and Kugler 2003, F302, F322). The result here is also only mildly discordant with the effect estimated by Borjas and Monras (2017), which is detrimental but statistically insignificant.

\subsection{The Mariel Boatlift again}

Borjas and Monras (2017) also revisit the impact of the Mariel Boatlift - differently from Borjas (2017) — adding variation across education groups and using the same instrumental variables regression specification across area-skill cells in equation (1). They concur with Card (1990) that the Mariel Boatlift had no detrimental impact on native employment. But like Borjas (2017), they find large negative wage impacts.

\footnotetext{
${ }^{37}$ Calculated, as above by: $-0.0132 \cdot \frac{1-0.05}{0.05}=-0.26$.
} 
The above reanalysis of the Mariel Boatlift episode, however, likewise implies that the Borjas and Monras (2017) results on the Mariel Boatlift are explained by irrelevant compositional shifts in the underlying data. This is because the entire result in Borjas and Monras's city-skill cell regressions depends on a single cell: workers with less-than-highschool in Miami. Table 13 demonstrates this: Column 1 exactly replicates the core Mariel Boatlift result in Borjas and Monras. Column 2 shows that the negative effect on native wages vanishes if a single data point is dropped: less-than-high-school in Miami. The same is true without any skill cell in Miami (col. 3) or without the less-than-high-school skill group in any city (col. 4).

Because the Borjas and Monras result for the Mariel Boatlift depends entirely on the decline in wages observed for the less-than-high-school subpopulation in Miami-which is identical to the subpopulation in Borjas (2017) — this means that the core problems of subsample sensitivity and compositional changes discussed in section 1 equally explain the different estimates of wage impacts in Borjas and Monras (2017) relative to Card (1990). And for employment impacts there is no discrepancy to explain: Both studies find no impact on employment.

Table 13 furthermore shows that the effect in Miami estimated by Borjas and Monras is absent among Hispanics. Column 5 reproduces their original result when city-skill cells with no Hispanic observations are omitted from the regression, and column 6 shows thatin the same sample - the result is absent when the wage changes within city-skill cells are estimated for Hispanic workers only. Instrumentation remains very strong (KleibergenPaap $F$ statistic of 1965) but the second-stage coefficient on the supply shock is statistically insignificant, and the Anderson-Rubin $F$-test has a $p$-value of 0.76 .

\section{Discussion}

Reanalysis of prior results often advances social science (Clemens 2017). Recent reanalyses of four early results on the labor market effects of refugee waves have reached conclusions markedly different from the original studies in two cases (Miami and Israel) and similar 
to the original studies in the other two cases (France and Europe). The origin of the discrepancies has not previously been clarified in a way that can assist researchers in reconciling these findings.

We offer simple and transparent methodological reasons for the discrepancies in this refugee-wave literature. For the Mariel Boatlift, all important discrepancies between the original analysis and reanalyses can be explained by the sensitivity of the results to the selection of small subsamples, often without a clear theoretical basis. In one small subsample that has received focus, there was a large, simultaneous, and irrelevant change in the racial composition of the original survey data. For the arrival of Soviet refugees in Israel, all important discrepancies between the original analysis and reanalysis can be explained by specification choices in the construction of the instrumental variable. For the refugee waves from Algeria to France and from the Balkans throughout Europe, there is little substantive discrepancy between the original studies and reanalyses. But even the limited discrepancies are reduced by the same specification correction to the construction of the instrumental variable, as shown in Appendix Table 2.

After accounting for the potential for spurious results from compositional change within subgrouped data and from the ratio-correlation problem for constructed instruments, the evidence from refugee waves collectively supports the existing consensus that the impact of immigration on average native-born workers is small. It does not support claims of large detrimental impacts on workers with less than high school education.

\section{References}

Acemoğlu, Daron and David Autor, "Skills, Tasks and Technologies: Implications for Employment and Earnings," in David Card and Orley Ashenfelter, eds., Handbook of Labor Economics, Vol. 4b, Amsterdam: Elsevier, 2011.

Altonji, Joseph G and David Card, "The effects of immigration on the labor market outcomes of less-skilled natives," in John M. Abowd and Richard B. Freeman, eds., Immigration, Trade, and the Labor Market, Chicago: University of Chicago Press, 1991, pp. 201-234.

- and Paul J Devereux, "The extent and consequences of downward nominal wage rigidity," in "Research in Labor Economics," Emerald Group, 2000, pp. 383-431.

Anderson, Theodore $\mathbf{W}$ and Herman Rubin, "Estimation of the parameters of a single 
equation in a complete system of stochastic equations," Annals of Mathematical Statistics, 1949, $20(1), 46-63$.

Angrist, Joshua D and Adriana D Kugler, "Protective or counter-productive? Labour market institutions and the effect of immigration on EU natives," Economic Journal, 2003, 113 (488), F302-F331.

- and Alan Krueger, "Empirical Strategies in Labor Economics," in O. Ashenfelter, ed., Handbook of Labor Economics, 1 ed., Vol. 3, No. 31999.

Bazzi, Samuel and Michael A Clemens, "Blunt instruments: avoiding common pitfalls in identifying the causes of economic growth," American Economic Journal: Macroeconomics, 2013, 5 (2), 152-186.

Blau, Francine D and Christopher Mackie, eds, The Economic and Fiscal Consequences of Immigration, Washington, DC: National Academies Press, 2016.

Borjas, George J, "Immigrants, minorities, and labor market competition," ILR Review, 1987, $40(3), 382-392$.

_ , "The Wage Impact of the Marielitos: A Reappraisal," ILR Review, 2017, forthcoming.

- and Joan Monras, "The Labor Market Consequences of Refugee Supply Shocks," Economic Policy, 2017, forthcoming.

Brooks, Camilla A and Barbara A. Bailar, An error profile: employment as measured by the Current Population Survey, [Washington]: U.S. Dept. of Commerce, Office of Federal Statistical Policy and Standards, 1978.

Burbidge, John B, Lonnie Magee, and A Leslie Robb, "Alternative transformations to handle extreme values of the dependent variable," Journal of the American Statistical Association, 1988, 83 (401), 123-127.

Bureau of the Census, Statistical Abstract of the United States 1981, 102 ${ }^{\text {nd }}$ ed., Washington, DC: U.S. Dept. of Commerce, 1982.

Cahuc, Pierre, Stephan Carcillo, and André Zylberberg, Labor Economics, 2 ed., Cambridge, MA: MIT Press, 2014.

Card, David, "The impact of the Mariel boatlift on the Miami labor market," ILR Review, 1990, $43(2), 245-257$.

_. "Immigration and Inequality," American Economic Review, 2009, 99 (2), 1-21.

Census Bureau, "Current Population Survey, March 1982: Tape, Technical Documentation," Washington, DC: U.S. Dept. of Commerce, Bureau of the Census 1982.

Clemens, Michael A, "The meaning of failed replications: A review and proposal," Journal of Economic Surveys, 2017, 31 (1), 326-342.

Dunn, Marvin, Black Miami in the Twentieth Century, Gainesville: University Press of Florida, 1997.

Durant, Thomas and Lenus Jack, "Undercount of black inner city residents of New Orleans, Louisiana," EV 93-27. Conducted under Joint Statistical Agreement to investigate the behavioral causes of undercount. Washington, DC: Bureau of the Census, Statistical Research Division 1993.

Festy, Patrick, "Le recensement de 1968 : quelques résultats," Population (French Edition), 1970, $25(2), 381-391$. 
Friedberg, Rachel M, "The impact of mass migration on the Israeli labor market," Quarterly Journal of Economics, 2001, 116 (4), 1373-1408.

Guillon, Michelle, "Les rapatriés d'Algérie dans la région parisienne," Annales de Géographie, 1974, 83 (460), 644-675.

Hainer, Peter, Catherine Hines, Elizabeth Martin, and Gary Shapiro, "Research on improving coverage in household surveys," in "Proceedings of the Fourth Annual Research Conference, March 20-23" Washington, DC: U.S. Bureau of the Census 1988, pp. 513-539.

Hamel, Harvey R and John T Tucker, "Implementing the Levitan Commission's recommendations to improve labor data," Monthly Labor Review, 1985, 108 (2), 16-24.

Hirsch, Barry $\mathbf{T}$ and Edward J Schumacher, "Match bias in wage gap estimates due to earnings imputation," Journal of labor economics, 2004, 22 (3), 689-722.

Hunt, Jennifer, "The impact of the 1962 repatriates from Algeria on the French labor market," ILR Review, 1992, 45 (3), 556-572.

Jackson, DA and KM Somers, "The spectre of spurious correlations," Oecologia, 1991, 86 (1), $147-151$.

Johnson, George E, "The labor market effects of immigration," ILR Review, 1980, 33 (3), 331-341.

Kerr, Sari Pekkala and William Kerr, "Economic Impacts of Immigration: A Survey," Finnish Economic Papers, 2011, 24 (1), 1-32.

Kleibergen, Frank and Richard Paap, "Generalized reduced rank tests using the singular value decomposition," Journal of Econometrics, 2006, 133 (1), 97-126.

Kronmal, Richard A, "Spurious correlation and the fallacy of the ratio standard revisited," Journal of the Royal Statistical Society. Series A (Statistics in Society), 1993, 156 (3), 379-392.

Levitan, Sar A et al., Counting the Labor Force, Washington, DC: National Commission on Employment and Unemployment Statistics, 1979.

Lewis, Ethan G, "Immigrant-Native Substitutability and The Role of Language," in David Card and Steven Raphael, eds., Immigration, Poverty, and Socioeconomic Inequality, New York: Russell Sage Foundation, 2013, pp. 60-97.

MacKinnon, James G and Lonnie Magee, "Transforming the dependent variable in regression models," International Economic Review, 1990, 31 (2), 315-339.

McManus, Walter, "Labor Market Effects of Language Enclaves: Hispanic Men in the United States," Journal of Human Resources, 1990, 25 (2), 228-252.

Neumark, David and Daiji Kawaguchi, "Attrition bias in labor economics research using matched CPS files," Journal of Economic and Social Measurement, 2004, 29 (4), 445-472.

Neyman, Jerzy, Lectures and Conferences on Mathematical Statistics and Probability, 2nd ed., Washington, DC: Graduate School, U.S. Dept. of Agriculture, 1952.

Pearson, Karl, "Mathematical contributions to the theory of evolution. On a form of spurious correlation which may arise when indices are used in the measurement of organs," Proceedings of the Royal Society of London, 1896, 60 (359-367), 489-498.

Pendleton, Brian F, Isadore Newman, and Rodney S Marshall, "A Monte Carlo approach to correlational spuriousness and ratio variables," Journal of Statistical Computation and Simulation, 1983, 18 (2-3), 93-124. 
_ , Richard D Warren, and HC Chang, "Correlated denominators in multiple regression and change analyses," Sociological Methods \& Research, 1979, 7 (4), 451-474.

Pendleton, Clarence M. et al., Confronting Racial Isolation in Miami, Washington, DC: U.S. Commission on Civil Rights, 1982.

Peri, Giovanni and Chad Sparber, "Task specialization, immigration, and wages," American Economic Journal: Applied Economics, 2009, 1 (3), 135-169.

- and Vasil Yasenov, "The Labor Market Effects of a Refugee Wave: Applying the Synthetic Control Method to the Mariel Boatlift," NBER Working Paper 21801. Revised from 2015 version. Cambridge, MA: National Bureau of Economic Research 2017.

Portes, Alejandro, Alex Stepick, and Cynthia Truelove, "Three years later: the adaptation process of 1980 (Mariel) Cuban and Haitian refugees in South Florida," Population Research and Policy Review, 1986, 5 (1), 83-94.

_ and _, "Unwelcome immigrants: the labor market experiences of 1980 (Mariel) Cuban and Haitian refugees in South Florida.," American Sociological Review, 1985, 50 (4), 493-514.

Robison, Edwin and Christopher Grieves, "Panel Analysis of Household Nonresponse and Person Coverage in the Current Population Survey," in "Survey Research Methods Section at the Joint Statistical Meetings of the American Statistical Association, Boston" 2014.

Roux, Michel, Les harkis ou les oubliés de l'histoire, Paris: Éditions La Découverte, 1991.

Ruggles, Steven, Katie Genadek, Ronald Goeken, Josiah Grover, and Matthew Sobek, "Integrated Public Use Microdata Series: Version 6.0 [dataset].," Minneapolis: University of Minnesota 2015.

Starsinic, Donald E. and Richard L. Forstall, Patterns of Metropolitan Area and County Population Growth: 1980 to 198\%. Current Population Reports P-25, No. 1039, Washington, DC: U.S. Dept. of Commerce, Bureau of the Census, 1989.

Stepick, Alex and Alejandro Portes, "Flight into Despair: A Profile of Recent Haitian Refugees in South Florida," International Migration Review, 1986, 20 (2), 329-350.

Stock, James, Motohiro Yogo, and Donald WK Andrews, "Testing for Weak Instruments in Linear IV Regression," Identification and Inference for Econometric Models, 2005, pp. 80-108.

U.S. Senate, Undercount and the 1980 decennial census, Hearing before the Subcommittee on Energy, Nuclear Proliferation, and Federal Services of the Committee on Governmental Affairs. United States Senate, Ninety-sixth Congress, second session, November 18, 1980. Washington, DC: Government Printing Office, 1981.

Wiseman, Robert M, "On the use and misuse of ratios in strategic management research," in "Research methodology in strategy and management," Emerald Group Publishing Limited, 2009, pp. $75-110$.

Young, Alwyn, "Consistency without Inference: Instrumental Variables in Practical Application," Working Paper, Dept. of Economics, London School of Economics 2017. 
Figure 1: Average low-Skill Wages in Miami: March CPS

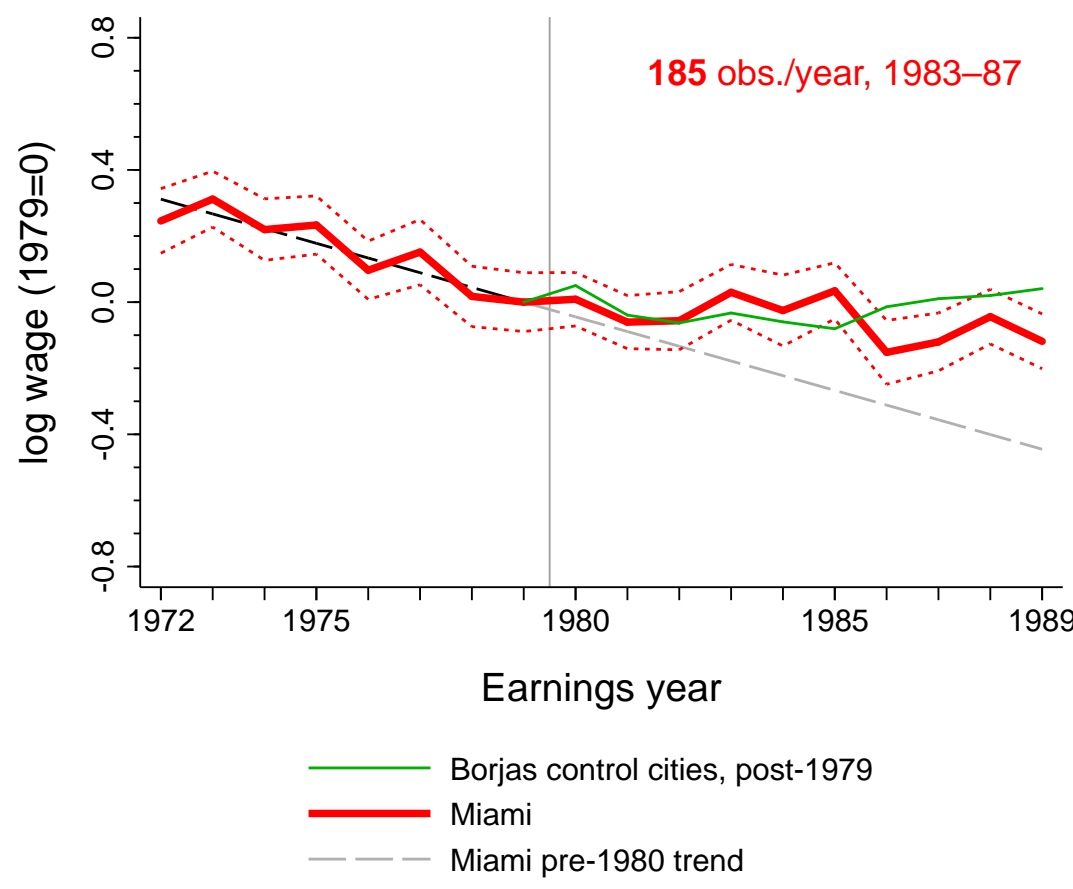

Thick red line shows average wage in Miami, with dotted line showing $95 \%$ confidence interval for the annual mean, calculated using Supplement Weight. Dashed line shows post-1980 continuation of pre-1980 linear trend in Miami. Thin green line shows average wage of same type of workers in the control cities preferred by Borjas (2017): Anaheim, Rochester, Nassau-Suffolk, and San Jose, calculated using Supplement Weight. Data from March CPS. 'Earnings year' is the year prior to the survey year, following Borjas (2017). 'Low-skill' means workers with high school or less. Wages are for non-Cuban workers age 19-65 with high school or less, who report positive annual wage and salary income, positive weeks worked, and positive usual hours worked weekly. 
Figure 2: Average LOW-Skill Wages in Miami: March CPS subgroups

(a) Men only

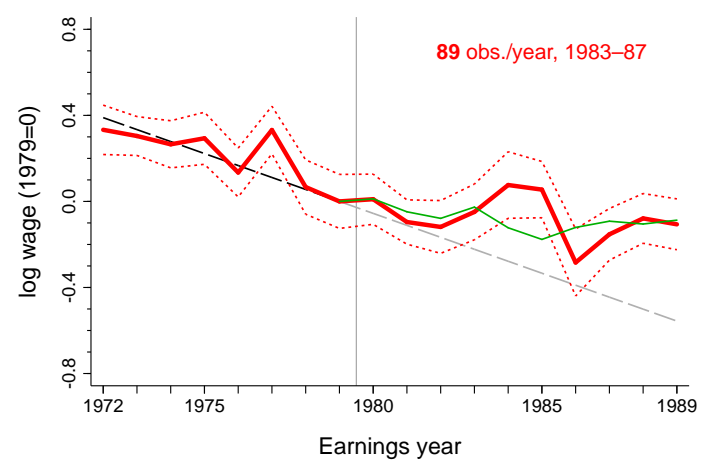

(c) Prime age only

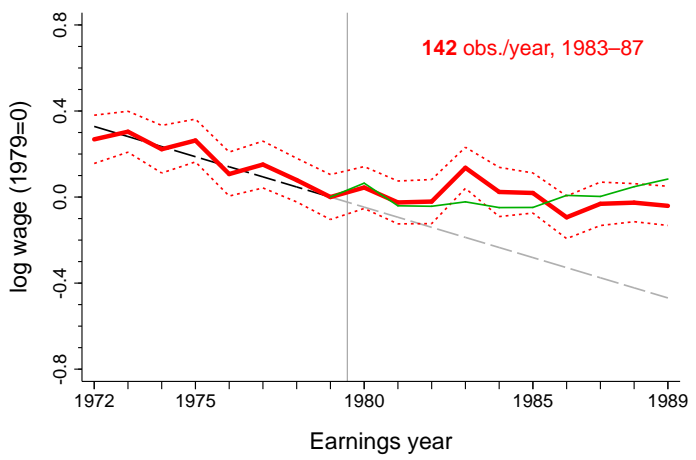

(e) Less than high school

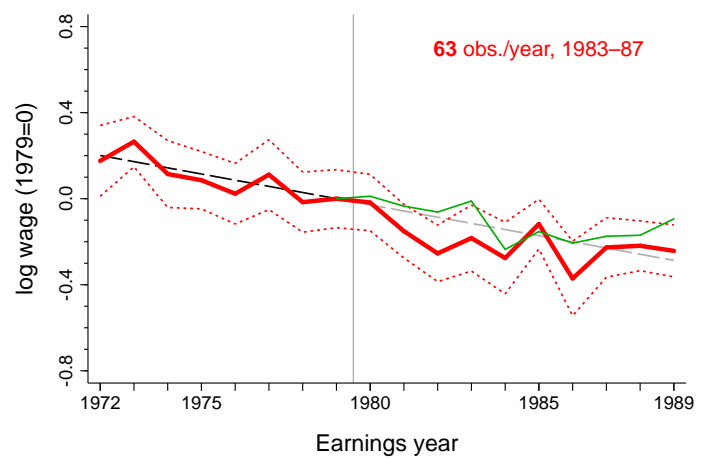

(b) Hispanics only

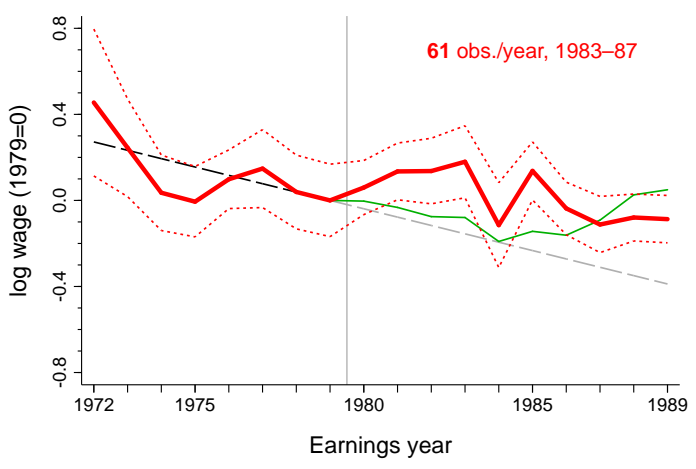

(d) High school only

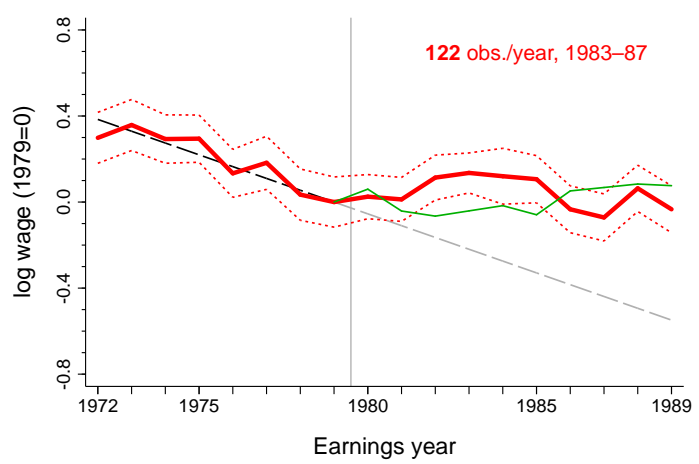

(f) Borjas subsample

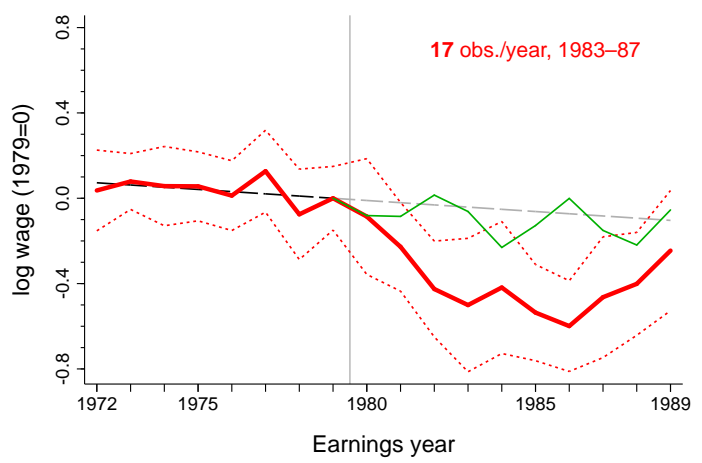

\footnotetext{
- Borjas control cities, post-1979

Miami

_ _ _ Miami pre-1980 trend
}

March CPS data. 'Earnings year' is year before survey year. 'Low-skill': high school or less. 'Borjas subsample': omits Hispanics, females, age $<25$, age $>59$, and high school only. 'Workers' report positive annual wage \& salary income, positive weeks worked, and positive usual hours worked weekly. Thick red line: annual average wage in Miami, with 95\% confidence interval, using Supplement Weight. Dashed line: pre-1980 linear trend in Miami. Thin green line: average wage of same type of workers in Borjas control cities, using Supplement Weight. 
Table 1: Blacks in CPS subsamples

\begin{tabular}{|c|c|c|c|c|c|c|}
\hline \multirow[b]{3}{*}{$\begin{array}{l}\text { Survey } \\
\text { year }\end{array}$} & \multicolumn{3}{|c|}{ Miami } & $\begin{array}{l}\text { Card } \\
\text { control }\end{array}$ & $\begin{array}{l}\text { Borjas } \\
\text { control }\end{array}$ & \multirow{2}{*}{$\begin{array}{c}\text { Miami } \\
\text { HS } \\
\text { or less }\end{array}$} \\
\hline & \multicolumn{5}{|c|}{ Less than high school } & \\
\hline & $\begin{array}{c}N \\
\text { black }\end{array}$ & $\begin{array}{l}N \text { non- } \\
\text { black }\end{array}$ & \multicolumn{4}{|c|}{ Fraction black } \\
\hline \multicolumn{7}{|c|}{ March CPS } \\
\hline 1977 & 11 & 12 & 0.479 & 0.267 & 0.028 & 0.408 \\
\hline 1978 & 10 & 16 & 0.372 & 0.343 & 0.086 & 0.394 \\
\hline 1979 & 8 & 14 & 0.363 & 0.304 & 0.135 & 0.442 \\
\hline 1980 & 9 & 8 & 0.630 & 0.317 & 0.107 & 0.505 \\
\hline 1981 & 11 & 7 & 0.663 & 0.279 & 0.073 & 0.512 \\
\hline 1982 & 11 & 9 & 0.653 & 0.341 & 0.019 & 0.456 \\
\hline 1983 & 17 & 10 & 0.673 & 0.284 & 0.000 & 0.465 \\
\hline 1984 & 11 & 7 & 0.634 & 0.266 & 0.135 & 0.363 \\
\hline 1985 & 14 & 2 & 0.910 & 0.276 & 0.180 & 0.541 \\
\hline 1986 & 11 & 4 & 0.753 & 0.295 & 0.098 & 0.569 \\
\hline 1987 & 13 & 3 & 0.822 & 0.335 & 0.052 & 0.605 \\
\hline 1988 & 13 & 5 & 0.767 & 0.198 & 0.237 & 0.543 \\
\hline 1989 & 9 & 8 & 0.610 & 0.289 & 0.229 & 0.533 \\
\hline 1990 & 10 & 6 & 0.728 & 0.327 & 0.115 & 0.541 \\
\hline \multicolumn{7}{|c|}{ May/ORG CPS } \\
\hline 1977 & 10 & 6 & 0.660 & 0.348 & 0.097 & 0.509 \\
\hline 1978 & 6 & 6 & 0.534 & 0.322 & 0.121 & 0.474 \\
\hline 1979 & 34 & 22 & 0.600 & 0.290 & 0.123 & 0.471 \\
\hline 1980 & 35 & 20 & 0.644 & 0.299 & 0.109 & 0.534 \\
\hline 1981 & 34 & 17 & 0.703 & 0.301 & 0.091 & 0.596 \\
\hline 1982 & 27 & 12 & 0.720 & 0.300 & 0.068 & 0.551 \\
\hline 1983 & 33 & 17 & 0.679 & 0.311 & 0.095 & 0.474 \\
\hline 1984 & 28 & 20 & 0.604 & 0.309 & 0.163 & 0.449 \\
\hline 1985 & 22 & 4 & 0.862 & 0.292 & 0.121 & 0.650 \\
\hline 1986 & 27 & 9 & 0.783 & 0.307 & 0.078 & 0.567 \\
\hline 1987 & 28 & 18 & 0.646 & 0.332 & 0.055 & 0.533 \\
\hline 1988 & 26 & 11 & 0.745 & 0.255 & 0.087 & 0.571 \\
\hline 1989 & 24 & 13 & 0.683 & 0.321 & 0.041 & 0.567 \\
\hline 1990 & 20 & 18 & 0.572 & 0.287 & 0.112 & 0.519 \\
\hline
\end{tabular}

Year shows year the survey was conducted, matching Borjas (2017, Table 3A). All samples include only male nonHispanic workers age 25-59. March CPS black fraction calculated using Supplement weight, May/ORG calculated using earnings weight. Unweighted fractions are similar. The Card preferred control cities are Atlanta, Los Angeles, Houston, and Tampa-St. Petersburg; the Borjas preferred control cities are Anaheim, Rochester, Nassau-Suffolk, and San Jose. 


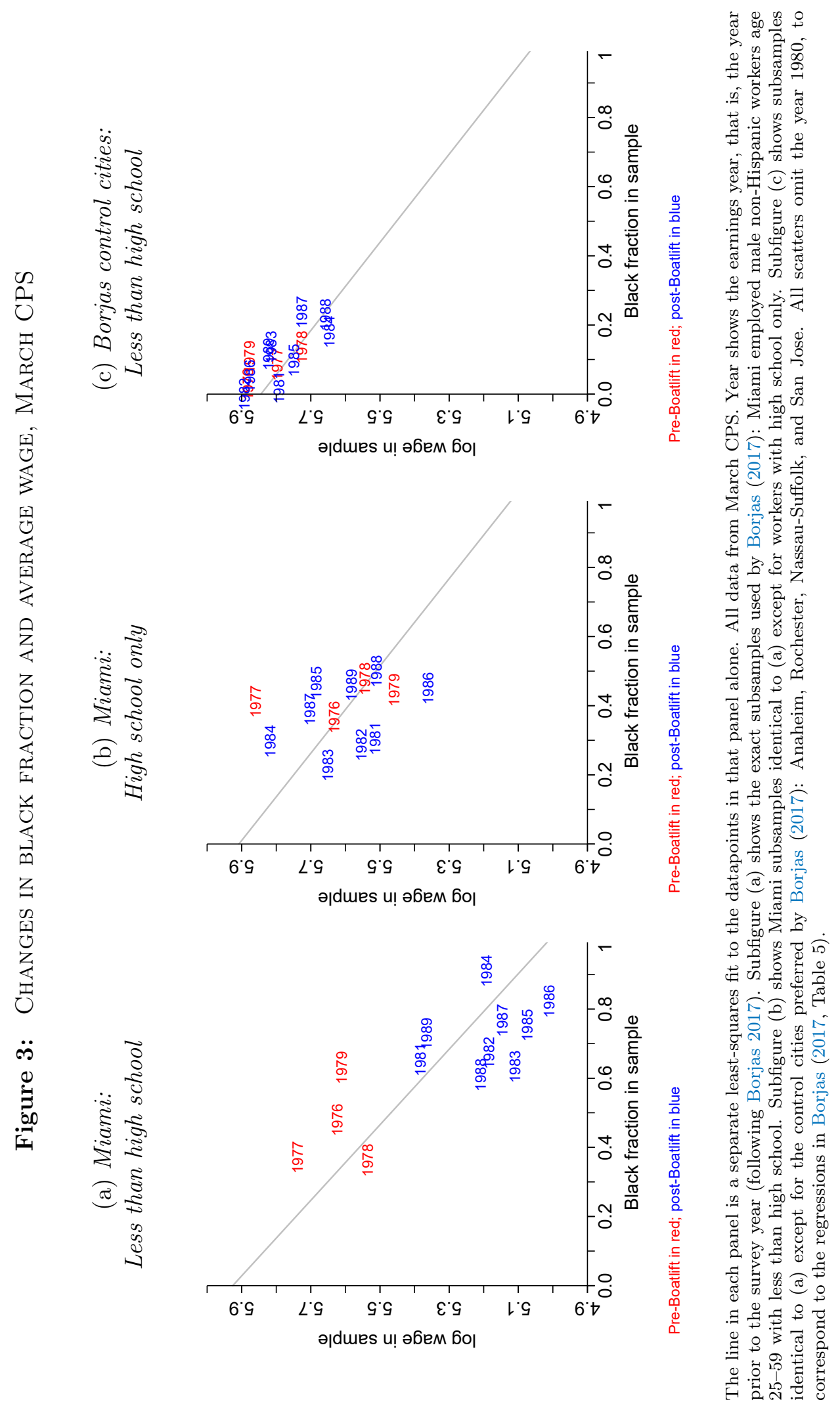


Table 2: Reanalysis of Borjas (2017), Table 5: With Black indicator

(a) March CPS extract

\begin{tabular}{|c|c|c|c|c|c|c|c|c|}
\hline \multirow[b]{4}{*}{$\begin{array}{r}\text { Control } \\
\text { cities: }\end{array}$} & (1) & $(2)$ & $(3)$ & (4) & (5) & (6) & (7) & (8) \\
\hline & & & \multicolumn{6}{|c|}{ Add indicator for black } \\
\hline & \multicolumn{2}{|c|}{ Exact replication } & \multicolumn{2}{|c|}{ Nationwide } & \multicolumn{2}{|c|}{ By city } & \multicolumn{2}{|c|}{$\begin{array}{c}\text { By city- } \\
\text { less than HS }\end{array}$} \\
\hline & Card & Borjas & Card & Borjas & Card & Borjas & Card & Borjas \\
\hline $1981-83$ & $\begin{array}{c}-0.204^{* * *} \\
(0.076)\end{array}$ & $\begin{array}{l}-0.290^{* * *} \\
(0.073)\end{array}$ & $\begin{array}{c}-0.121 \\
(0.078)\end{array}$ & $\begin{array}{l}-0.194^{* * *} \\
(0.070)\end{array}$ & $\begin{array}{c}-0.096 \\
(0.081)\end{array}$ & $\begin{array}{c}-0.174^{* *} \\
(0.072)\end{array}$ & $\begin{array}{c}0.001 \\
(0.062)\end{array}$ & $\begin{array}{c}-0.078 \\
(0.061)\end{array}$ \\
\hline $1984-86$ & $\begin{array}{c}-0.368^{* * *} \\
(0.060)\end{array}$ & $\begin{array}{c}-0.454^{* * *} \\
(0.059)\end{array}$ & $\begin{array}{c}-0.202^{* * *} \\
(0.072)\end{array}$ & $\begin{array}{c}-0.301^{* * *} \\
(0.053)\end{array}$ & $\begin{array}{c}-0.137 \\
(0.083)\end{array}$ & $\begin{array}{c}-0.227^{* * *} \\
(0.058)\end{array}$ & $\begin{array}{c}0.109^{*} \\
(0.063)\end{array}$ & $\begin{array}{c}-0.001 \\
(0.059)\end{array}$ \\
\hline $1987-89$ & $\begin{array}{c}-0.329^{* * *} \\
(0.081)\end{array}$ & $\begin{array}{c}-0.303^{* * *} \\
(0.072)\end{array}$ & $\begin{array}{c}-0.202^{* *} \\
(0.093)\end{array}$ & $\begin{array}{l}-0.237^{* * *} \\
(0.071)\end{array}$ & $\begin{array}{r}-0.135 \\
(0.089)\end{array}$ & $\begin{array}{c}-0.149^{* *} \\
(0.066)\end{array}$ & $\begin{array}{c}-0.025 \\
(0.098)\end{array}$ & $\begin{array}{c}-0.049 \\
(0.070)\end{array}$ \\
\hline $1990-92$ & $\begin{array}{c}-0.026 \\
(0.072)\end{array}$ & $\begin{array}{c}-0.056 \\
(0.123)\end{array}$ & $\begin{array}{c}0.094 \\
(0.086)\end{array}$ & $\begin{array}{c}0.025 \\
(0.117)\end{array}$ & $\begin{array}{c}0.105 \\
(0.089)\end{array}$ & $\begin{array}{c}0.037 \\
(0.112)\end{array}$ & $\begin{array}{c}0.220 \\
(0.134)\end{array}$ & $\begin{array}{c}0.121 \\
(0.103)\end{array}$ \\
\hline$N$ & 75 & 75 & 75 & 75 & 75 & 75 & 75 & 75 \\
\hline
\end{tabular}

(b) May/ORG CPS extract

\begin{tabular}{|c|c|c|c|c|c|c|c|c|}
\hline & (1) & (2) & (3) & (4) & (5) & $(6)$ & (7) & (8) \\
\hline & & & & & dd indica & or for black & & \\
\hline & Exact rep & plication & Nati & nwide & & city & $\begin{array}{r}\mathrm{By} \\
\text { less tl }\end{array}$ & $\begin{array}{l}\text { ity- } \\
\text { an HS }\end{array}$ \\
\hline $\begin{array}{r}\text { Control } \\
\text { cities: }\end{array}$ & Card & Borjas & Card & Borjas & Card & Borjas & Card & Borjas \\
\hline $1981-83$ & $\begin{array}{c}-0.075^{* * *} \\
(0.026)\end{array}$ & $\begin{array}{c}-0.140^{* * *} \\
(0.049)\end{array}$ & $\begin{array}{c}-0.047 \\
(0.029)\end{array}$ & $\begin{array}{c}-0.104^{* *} \\
(0.046)\end{array}$ & $\begin{array}{c}0.005 \\
(0.034)\end{array}$ & $\begin{array}{c}-0.056 \\
(0.040)\end{array}$ & $\begin{array}{c}0.036 \\
(0.034)\end{array}$ & $\begin{array}{r}-0.025 \\
(0.044)\end{array}$ \\
\hline $1984-86$ & $\begin{array}{c}-0.069 \\
(0.057)\end{array}$ & $\begin{array}{r}-0.116^{*} \\
(0.065)\end{array}$ & $\begin{array}{c}-0.024 \\
(0.067)\end{array}$ & $\begin{array}{c}-0.079 \\
(0.060)\end{array}$ & $\begin{array}{c}-0.001 \\
(0.063)\end{array}$ & $\begin{array}{c}-0.053 \\
(0.047)\end{array}$ & $\begin{array}{c}0.016 \\
(0.051)\end{array}$ & $\begin{array}{r}-0.033 \\
(0.047)\end{array}$ \\
\hline 1987-89 & $\begin{array}{c}-0.106^{* * *} \\
(0.036)\end{array}$ & $\begin{array}{c}-0.175^{* * *} \\
(0.064)\end{array}$ & $\begin{array}{r}-0.074^{*} \\
(0.039)\end{array}$ & $\begin{array}{c}-0.137^{* *} \\
(0.064)\end{array}$ & $\begin{array}{c}-0.046 \\
(0.042)\end{array}$ & $\begin{array}{c}-0.101 \\
(0.067)\end{array}$ & $\begin{array}{c}0.051 \\
(0.053)\end{array}$ & $\begin{array}{c}0.015 \\
(0.074)\end{array}$ \\
\hline 1990-92 & $\begin{array}{c}0.019 \\
(0.041)\end{array}$ & $\begin{array}{c}-0.070 \\
(0.062) \\
\end{array}$ & $\begin{array}{c}0.069 \\
(0.044) \\
\end{array}$ & $\begin{array}{c}-0.041 \\
(0.070) \\
\end{array}$ & $\begin{array}{r}0.105^{*} \\
(0.055) \\
\end{array}$ & $\begin{array}{c}-0.004 \\
(0.076) \\
\end{array}$ & $\begin{array}{l}0.162^{* *} \\
(0.061)\end{array}$ & $\begin{array}{c}0.039 \\
(0.078) \\
\end{array}$ \\
\hline$N$ & 75 & 75 & 75 & 75 & 75 & 75 & 75 & 75 \\
\hline
\end{tabular}

Difference-in-difference regressions with pre-treatment period 1977-79. Year 1980 omitted since it includes both pre-treatment and post-treatment observations, as in Borjas (2017, Table 5). Unit of observation is city-year. Dependent variable is $\log$ weekly real wage. Robust standard errors in parentheses: ${ }^{*} p<0.10,{ }^{* *} p<0.05,{ }^{* * *}$ $p<0.01$. Sample is working non-Hispanic males age $25-59$ with less than high school. 'HS' is high school. The Card preferred control cities are Atlanta, Los Angeles, Houston, and Tampa-St. Petersburg; the Borjas preferred control cities are Anaheim, Rochester, Nassau-Suffolk, and San Jose. 'Nationwide' means coefficient on black indicator is constrained to take the same value for all cities and education levels; 'by city' means coefficient on black indicator takes a unique value for all blacks in each city; 'by city-less than HS' means coefficient on black indicator takes a unique value for blacks with less than high school in each city. 
Figure 4: Miami, March CPS: Average Wage in Borjas sample without Blacks

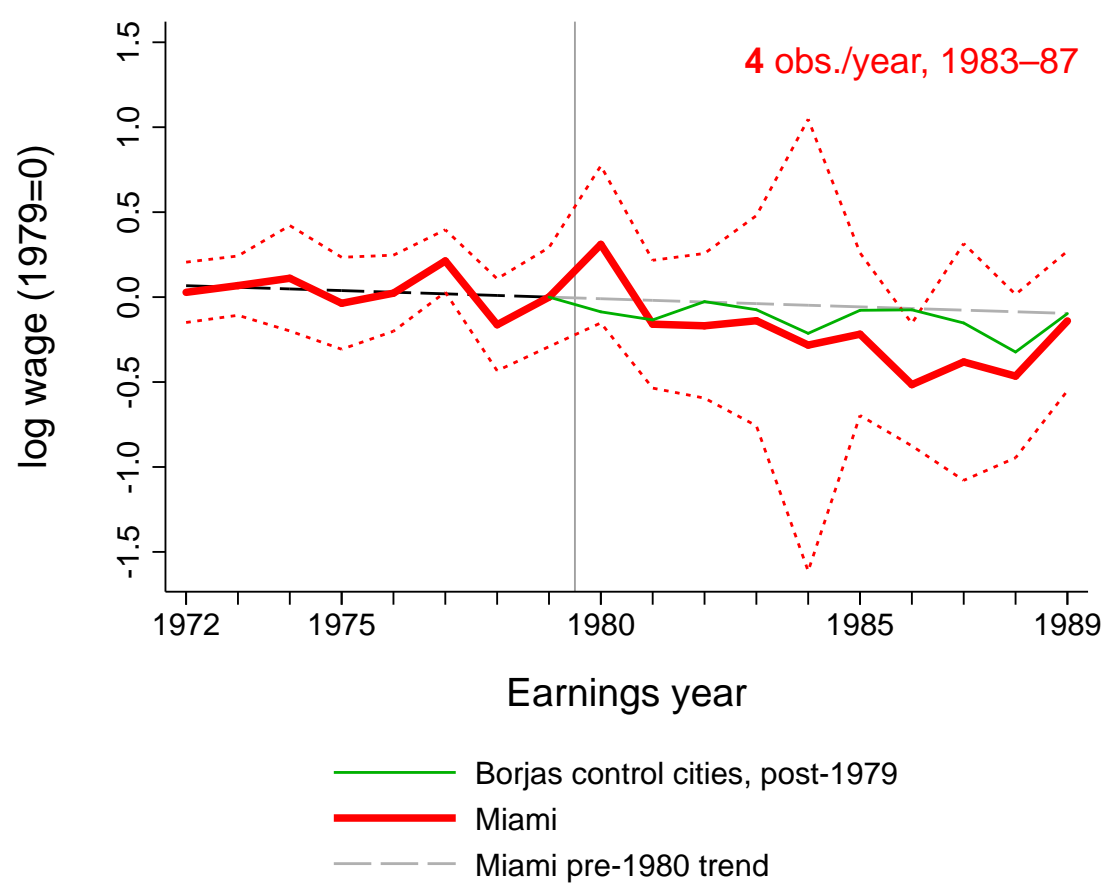

Data from March CPS. 'Earnings year' is the year prior to the survey year, following Borjas (2017). 'Borjas sample' is non-Hispanic male workers age $25-59$ with high school or less, who report positive annual wage and salary income, positive weeks worked, and positive usual hours worked weekly. Thick red line shows average wage in Miami, with dotted line showing 95\% confidence interval for the annual mean, calculated using Supplement Weight. Dashed line shows post-1980 continuation of pre-1980 linear trend in Miami. Thin green line shows average wage of same type of workers in the control cities preferred by Borjas (2017): Anaheim, Rochester, Nassau-Suffolk, and San Jose, calculated using Supplement Weight. 
Table 3: Wage and employment differences By RaCe, March CPS 1977-1986

\begin{tabular}{|c|c|c|c|c|c|c|}
\hline & (1) & $(2)$ & (3) & $(4)$ & $(5)$ & (6) \\
\hline & \multicolumn{2}{|c|}{ Miami } & \multicolumn{2}{|c|}{ Card control cities } & \multicolumn{2}{|c|}{ Borjas control cities } \\
\hline & Weighted & Unweighted & Weighted & Unweighted & Weighted & Unweighted \\
\hline \multicolumn{7}{|c|}{ Dep. var: log wage } \\
\hline Black & $\begin{array}{c}-0.487^{* * *} \\
(0.0737)\end{array}$ & $\begin{array}{c}-0.465^{* * *} \\
(0.0728)\end{array}$ & $\begin{array}{c}-0.219^{* * *} \\
(0.0315)\end{array}$ & $\begin{array}{c}-0.215^{* * *} \\
(0.0321)\end{array}$ & $\begin{array}{c}-0.285^{* * *} \\
(0.0760)\end{array}$ & $\begin{array}{c}-0.261^{* * *} \\
(0.0770)\end{array}$ \\
\hline \multicolumn{7}{|c|}{ Dep. var: Unemployed $(0,1)$} \\
\hline Black & $\begin{array}{c}-0.00480 \\
(0.0320)\end{array}$ & $\begin{array}{c}-0.00345 \\
(0.0302)\end{array}$ & $\begin{array}{l}0.0688^{* * *} \\
(0.0158)\end{array}$ & $\begin{array}{l}0.0513^{* * *} \\
(0.0155)\end{array}$ & $\begin{array}{c}\text { * } \quad 0.0528^{* * *} \\
(0.0122)\end{array}$ & $\begin{array}{l}0.0515^{* *} \\
(0.0124)\end{array}$ \\
\hline
\end{tabular}

Regressor is an indicator variable equal to 1 for black, 0 otherwise. Coefficients are from a pooled OLS regression of each outcome on the black dummy and a constant term, and nothing else. Standard errors in parentheses. ${ }^{*} p<0.10,{ }^{* *} p<0.05,{ }^{* * *} p<0.01$. The weighted regressions use the March Supplement weight. Wage regressions: The sample is identical to the March CPS sample in Borjas (2017, Table 3A), and includes only male non-Hispanic workers with less-than-high-school education, aged 25-59, who report positive annual wage and salary income, positive weeks worked, and positive usual hours worked weekly. Unemployment regressions: The sample is identical to the March CPS sample in Borjas and Monras (2017), and includes only male non-Hispanic workers with less-than-high-school education, aged 25-59. The unemployment regressions cannot be run using data from Borjas (2017) because that paper considers only employed workers, and tests for wage effects conditional on employment. 
Table 4: Israel: Placebo Regressions, Borjas and Monras (2017) model

(a) Israel: Mean 1983 Soviet stock by education, real vs. placebo

\begin{tabular}{lrr}
\hline Education group & Real & Placebo \\
\cline { 2 - 3 } Less than primary completed & 478.8 & 486.1 \\
Primary completed & 742.5 & 743.4 \\
Secondary completed & 1735.0 & 1736.1 \\
University completed & 1116.3 & 1116.3 \\
\hline
\end{tabular}

The placebo is a randomly-generated variable drawn from a Poisson distribution with the same mean as the real variable.

(b) Israel: Placebo reanalysis of Borjas and Monras Table 6, cols. 3 and 4

\begin{tabular}{lcccc}
\hline Dep. var.: $\Delta$ native wage & $(1)$ & $(2)$ & $(3)$ & $(4)$ \\
\multicolumn{1}{c}{ Lagged Soviet fraction IV: } & Real & Placebo & Real & Placebo \\
\cline { 2 - 5 } & & & & \\
Émigré supply shock/pop. & $-0.616^{*}$ & $-0.820^{* * *}$ & $-0.611^{*}$ & $-0.873^{*}$ \\
& $(0.316)$ & $(0.315)$ & $(0.334)$ & $(0.473)$ \\
Change in native population & & & -0.00352 & 0.0229 \\
& & & $(0.0707)$ & $(0.0976)$ \\
\hline$N$ & 32 & 32 & 32 & 32 \\
adj. $R^{2}$ & 0.286 & 0.289 & 0.258 & 0.257 \\
Kleibergen-Paap $F$ & 27.37 & 5.059 & 23.19 & 3.728 \\
$p$-val. Anderson-Rubin $F$-test & 0.0985 & 0.0272 & 0.113 & 0.0880 \\
\hline
\end{tabular}

Robust standard errors in parentheses. ${ }^{*} p<0.10,{ }^{* *} p<0.05,{ }^{* * *} p<0.01$. The instrument in each column is: (1) real 1983 Soviet fraction, (2) placebo 1983 Soviet fraction, (3) real 1983 Soviet fraction, (4) placebo 1983 Soviet fraction. All specifications include education and occupation fixed effects. 
Table 5: Israel: Kronmal specification CORReCtion to Borjas and Monras

(1)

Dependent variable:

Estimator:

Émigré supply shock/pop.

asinh émigré supply shock/pop.

asinh émigré supply shock

asinh total pop.

$$
\begin{array}{r}
-0.616^{*} \\
(0.316)
\end{array}
$$

(2)

$\Delta$ native wage

2SLS
(4)

asinh émigré supply shock

OLS

(3) 
Table 6: Israel: Placebo Regressions, Friedberg (2001) model

(a) Israel: Mean pre-migration stock per occupation, by education: real vs. placebo

\begin{tabular}{lrr}
\hline Years of educ. & Real & Placebo \\
\cline { 2 - 3 } Less than primary (0-8) & 7.257 & 7.199 \\
Primary completed (9-11) & 14.806 & 14.953 \\
Secondary completed (12) & 18.376 & 18.398 \\
Some college (13-14) & 29.206 & 29.295 \\
Tertiary completed (15-26) & 48.545 & 48.470 \\
\hline
\end{tabular}

The placebo is a randomly-generated variable drawn from a Poisson distribution with the same mean as the real variable.

(b) Israel: Placebo reanalysis of core result in Friedberg, Table III, row 4

\begin{tabular}{lcc}
\hline Dep. var.: $\Delta$ native wage & $(1)$ & $(2)$ \\
& & \\
\multicolumn{1}{c}{ Lagged Soviet fraction $I V:$} & Real & Placebo \\
\cline { 2 - 3 } & & \\
Émigré supply shock/pop. (' $r$ ') & $0.718^{* *}$ & 0.402 \\
& $(0.339)$ & $(0.807)$ \\
\hline$N$ & 8353 & 8353 \\
adj. $R^{2}$ & 0.520 & 0.523 \\
Kleibergen-Paap $F$ & 42.23 & 3.570 \\
$p$-val. Anderson-Rubin $F$-test & 0.0195 & 0.594 \\
\hline
\end{tabular}

The émigré supply shock $r$ in the original study is Soviet émigrés in 1994, per Israeli in 1994 in each skill-occupation cell. The instrument in column 1 , as in the original study, is the number of the Soviet émigrés who were in each skill-occupation cell prior to migration, per Israeli who was in that cell in 1989. The instrument in column 2 is the Poisson white noise from Table 6a divided by the number of Israelis in the cell in 1989. Robust standard errors in parentheses. ${ }^{*} p<0.10,{ }^{* *} p<0.05,{ }^{* * *} p<0.01$. All specifications include education and occupation fixed effects. 
Table 7: Israel: Kronmal SPecification CORRection to FriedberG

\section{Dependent variable:}

Estimator:

Émigré supply shock/pop. (' $r$ ')

asinh émigré supply shock/pop.

asinh émigrés in cell, 1994

asinh Israelis in cell, 1994

asinh Israelis in cell, 1989
(1)

$(2)$

$\Delta$ native wage

2SLS

$0.718^{* *}$

$(0.339)$
(3)

$(4)$

asinh émigrés

in cell, 1994

OLS

\begin{tabular}{lcccc} 
& \multicolumn{3}{c}{} & $(0.00233)$ \\
$N$ & 8353 & 8353 & 8353 & 8353 \\
adj. $R^{2}$ & 0.520 & 0.520 & 0.519 & 0.897 \\
Kleibergen-Paap F & 42.23 & 38.37 & 5.819 & \\
$p$-val. Anderson-Rubin F-test & 0.0195 & 0.0211 & 0.115 & - \\
\hline
\end{tabular}

asinh is inverse hyperbolic sine. Robust standard errors in parentheses. Square brackets show column 3 coefficient adjusted to be comparable to column 1 coefficient (dividing by immigrant fraction of labor force). ${ }^{*} p<0.10,{ }^{* *}$ $p<0.05,{ }^{* * *} p<0.01$. The émigré supply shock $r$ in the original study is Soviet émigrés in 1994, per Israeli in 1994 in each skill-occupation cell. The instrument in each column is: (1) the number of the Soviet émigrés who were in each skill-occupation cell prior to migration, per Israeli who was in that cell in 1989 (as in original); (2) asinh of the instrument in column 1; (3) asinh of the number of the Soviet émigrés who were in each skill-occupation cell prior to migration; (4) none. All specifications include education and occupation fixed effects. 
Table 8: France: Placebo Regressions, Borjas and Monras (2017) model

(a) France: Mean of 1962 Algerian stock by education, real vs. placebo

\begin{tabular}{lrr}
\hline Education group & Real & Placebo \\
\cline { 2 - 3 } Less than primary completed & 8020.0 & 8032.8 \\
Primary completed & 263.6 & 263.0 \\
Secondary completed & 83.6 & 81.8 \\
University completed & 30.0 & 29.4 \\
\hline
\end{tabular}

The placebo is a randomly-generated variable drawn from a Poisson distribution with the same mean as the real variable.

(b) France: Placebo reanalysis of Borjas and Monras Table 10, col. 3

\begin{tabular}{|c|c|c|c|c|c|}
\hline $\begin{array}{l}\text { Dep. var.: } \\
\Delta \text { native unemployment }\end{array}$ & (1) & $(2)$ & $(3)$ & (4) & $(5)$ \\
\hline Lagged Algerian fraction IV: & Real & Placebo & Real & Placebo & Placebo \\
\hline Repatriate supply shock/pop. & $\begin{array}{c}0.0887^{* *} \\
(0.0384)\end{array}$ & $\begin{array}{c}0.0488 \\
(0.0502)\end{array}$ & & & \\
\hline Algerian supply shock/pop. & $\begin{array}{l}0.247^{* * *} \\
(0.0667)\end{array}$ & $\begin{array}{l}0.419^{* * *} \\
(0.126)\end{array}$ & $\begin{array}{c}0.282^{* * *} \\
(0.0669)\end{array}$ & $\begin{array}{l}0.437^{* * *} \\
(0.117)\end{array}$ & $\begin{array}{l}0.443^{* * *} \\
(0.118)\end{array}$ \\
\hline Change in native population & & & & & $\begin{array}{c}0.00279 \\
(0.0123)\end{array}$ \\
\hline$N$ & 88 & 88 & 88 & 88 & 88 \\
\hline adj. $R^{2}$ & 0.460 & 0.392 & 0.432 & 0.368 & 0.355 \\
\hline Kleibergen-Paap $F$ & 54.23 & 2.440 & 247.7 & 5.285 & 5.116 \\
\hline$p$-val. Anderson-Rubin $F$-test & 0.000122 & 0.0000466 & 0.000542 & 0.00351 & 0.00382 \\
\hline
\end{tabular}

Robust standard errors in parentheses. ${ }^{*} p<0.10,{ }^{* *} p<0.05,{ }^{* * *} p<0.01$. The instrument set in each column is: (1) 1962 repatrie fraction and real 1962 Algerian fraction; (2) 1962 repatriate fraction and placebo 1962 Algerian fraction; (3) real 1962 Algerian fraction; (4) and (5) placebo 1962 Algerian fraction. All specifications include education fixed effects. 
Table 9: France: Kronmal specification correction to Borjas and Monras

$(1) \quad(2) \quad(3)$

Dependent variable:

Estimator:

Algerian supply

shock/pop.

asinh Algerian supply shock/pop.

asinh Algerian supply shock

asinh repatriate supply shock

asinh total native population

\begin{tabular}{cr}
\hline $0.282^{* * *}$ & \\
$(0.0669)$ & \\
& $0.282^{* * *}$ \\
& $(0.0669)$
\end{tabular}

(0.0669)
$\Delta$ native unemployment

\section{SLS}

(4)
(5)

asinh Algerian supply shock

OLS

$$
\begin{array}{cl}
0.00234^{* * *} & 0.00182^{* *} \\
(0.000836) & (0.000904) \\
& {[0.226]} \\
& 0.00151 \\
& (0.00249) \\
& {[0.044]}
\end{array}
$$

\begin{tabular}{lccccc}
$N$ & 88 & 88 & 88 & 88 & 88 \\
adj. $R^{2}$ & 0.432 & 0.432 & 0.301 & 0.344 & 0.808 \\
Kleibergen-Paap $F$ & 247.7 & 248.2 & 42.44 & 13.82 & - \\
$p$-val. And.-Rub. F-test & 0.000542 & 0.000543 & 0.0147 & 0.0154 & - \\
\hline
\end{tabular}

asinh is inverse hyperbolic sine. Robust standard errors in parentheses. Square brackets show column 4 coefficients adjusted to be comparable to column 1 coefficient (dividing by immigrant fraction of labor force). ${ }^{*} p<0.10,{ }^{* *}$ $p<0.05,{ }^{* * *} p<0.01$. The instruments in each column is: (1) 1962 Algerian stock/pop., (2) asinh of 1962 Algerian stock/pop.; (3) asinh of 1962 Algerian stock; (4) asinh of 1962 Algerian stock and asinh of 1962 repatriate stock (in the second stage, both 1968 stocks are considered endogenous); (5) none. All specifications include education fixed effects. 'asinh total native population' means asinh of 1968 total population minus the inflow of repatriates and Algerians. 


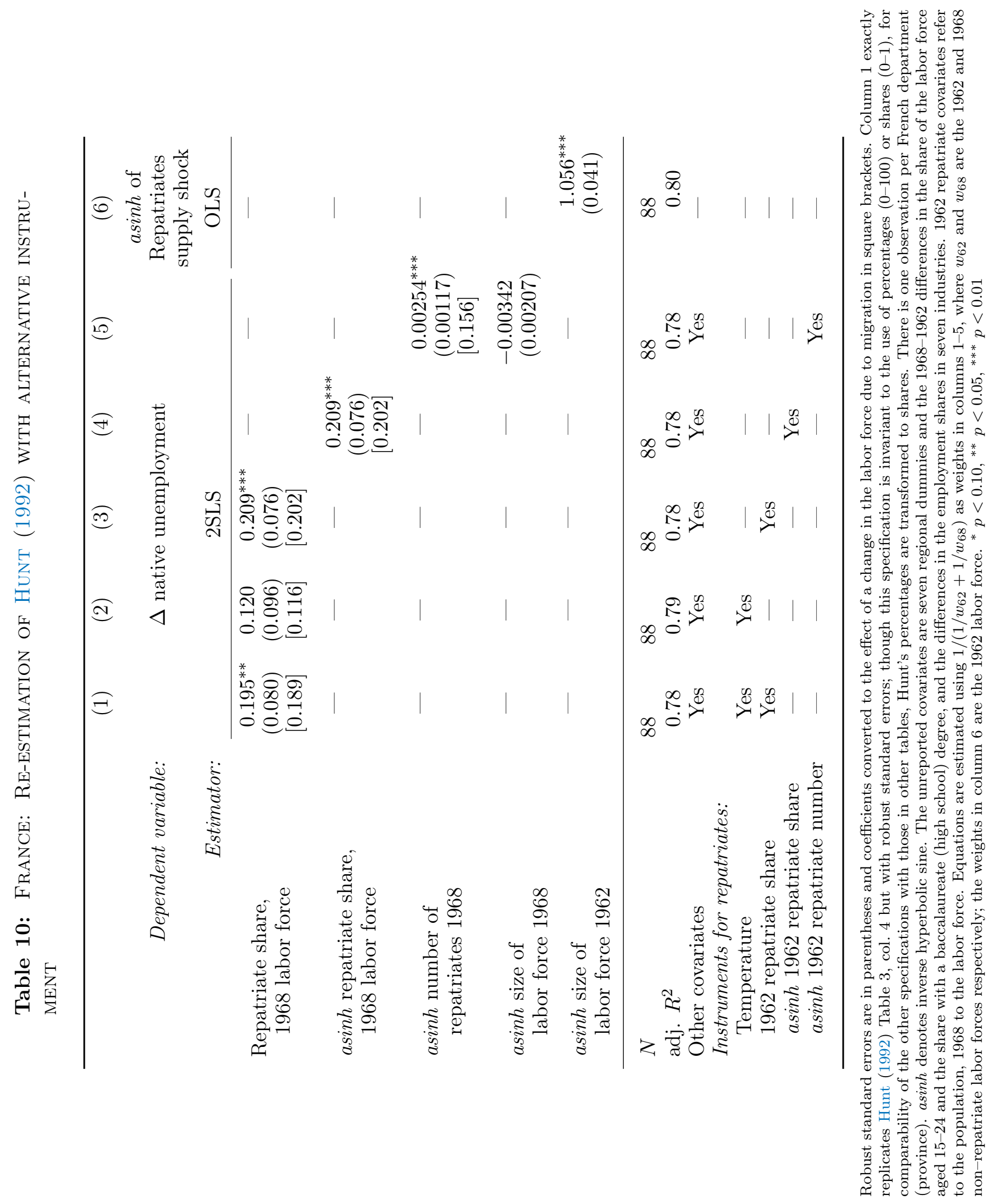


Table 11: Europe: Placebo regressions, Borjas and Monras (2017) model

(a) Europe: Mean 1990 Balkan stock by country, real vs. placebo

\begin{tabular}{lrr}
\hline Country & Real & Placebo \\
\cline { 2 - 3 } Austria & 2612.2 & 2615.0 \\
Greece & 6.2 & 6.3 \\
Ireland & 0.0 & 0.0 \\
Portugal & 2.9 & 2.5 \\
Romania & 11.3 & 11.4 \\
Spain & 0.0 & 0.0 \\
Switzerland & 3082.9 & 3096.1 \\
\hline
\end{tabular}

The placebo is a randomly-generated variable drawn from a Poisson distribution with the same mean as the real variable.

(b) Europe: Placebo reanalysis of Borjas and Monras Table 13, cols. 3 and 4

Dep. var.: $\Delta$ native unemployment

(1)

$(2)$

$(3)$

(4)

Lagged Balkan fraction IV: Real Placebo Real Placebo

Balkan supply shock/pop.

\begin{tabular}{cccc}
\hline 0.456 & $0.583^{*}$ & 0.487 & 0.657 \\
$(0.311)$ & $(0.323)$ & $(0.376)$ & $(0.510)$ \\
& & -0.00266 & -0.00426 \\
& & $(0.0165)$ & $(0.0181)$
\end{tabular}

Change in native pop.

195

195

195

195

adj. $R^{2}$

0.741

0.740

0.739

0.737

Kleibergen-Paap $F$

17.72

6.189

16.34

5.219

$p$-val. Anderson-Rubin $F$-test

0.122

0.0204

0.187

0.149

Robust standard errors in parentheses. ${ }^{*} p<0.10,{ }^{* *} p<0.05,{ }^{* * *} p<0.01$. The instrument in each column is: (1) real 1990 Balkan fraction, (2) placebo 1990 Balkan fraction, (3) real 1990 Balkan fraction, (4) placebo 1990 Balkan fraction. All specifications include education and country fixed effects. 
Table 12: Europe: Kronmal specification CORrection to Borjas and Monras

\begin{tabular}{|c|c|c|c|c|}
\hline \multirow{3}{*}{$\begin{array}{r}\text { Dependent variable: } \\
\text { Estimator: }\end{array}$} & (1) & $(2)$ & (3) & \multirow{2}{*}{$\begin{array}{c}\text { (4) } \\
\text { asinh Balkan } \\
\text { supply shock }\end{array}$} \\
\hline & \multicolumn{3}{|c|}{$\Delta$ native unemployment } & \\
\hline & \multicolumn{3}{|c|}{ 2SLS } & OLS \\
\hline Balkan supply shock/pop. & $\begin{array}{c}0.456 \\
(0.311)\end{array}$ & & & \\
\hline asinh Balkan supply shock/pop. & & $\begin{array}{c}0.459 \\
(0.314)\end{array}$ & & \\
\hline asinh Balkan supply shock & & & $\begin{array}{c}-0.0132 \\
(0.0119) \\
{[-0.26]}\end{array}$ & \\
\hline asinh total pop. (without Balkan) & & & $\begin{array}{c}0.00992 \\
(0.0125)\end{array}$ & $\begin{array}{l}0.955^{* * *} \\
(0.201)\end{array}$ \\
\hline$N$ & 195 & 195 & 195 & 195 \\
\hline adj. $R^{2}$ & 0.741 & 0.741 & 0.339 & 0.509 \\
\hline Kleibergen-Paap $F$ & 17.72 & 17.31 & 1.498 & - \\
\hline$p$-val. Anderson-Rubin $F$-test & 0.122 & 0.122 & 0.0209 & - \\
\hline
\end{tabular}

asinh is inverse hyperbolic sine. Robust standard errors in parentheses. Square brackets show column 3 coefficient adjusted to be comparable to column 1 coefficient (dividing by immigrant fraction of population). ${ }^{*} p<0.10,{ }^{* *}$ $p<0.05$, *** $p<0.01$. The instrument in each column is: (1) 1990 Balkan fraction, (2) asinh of 1990 Balkan fraction; (3) asinh of 1990 Balkan stock; (4) none. 'asinh total pop. without Balkan' means asinh of 2000 total population minus Balkan inflow 1990-2000. All specifications include education and country fixed effects. 


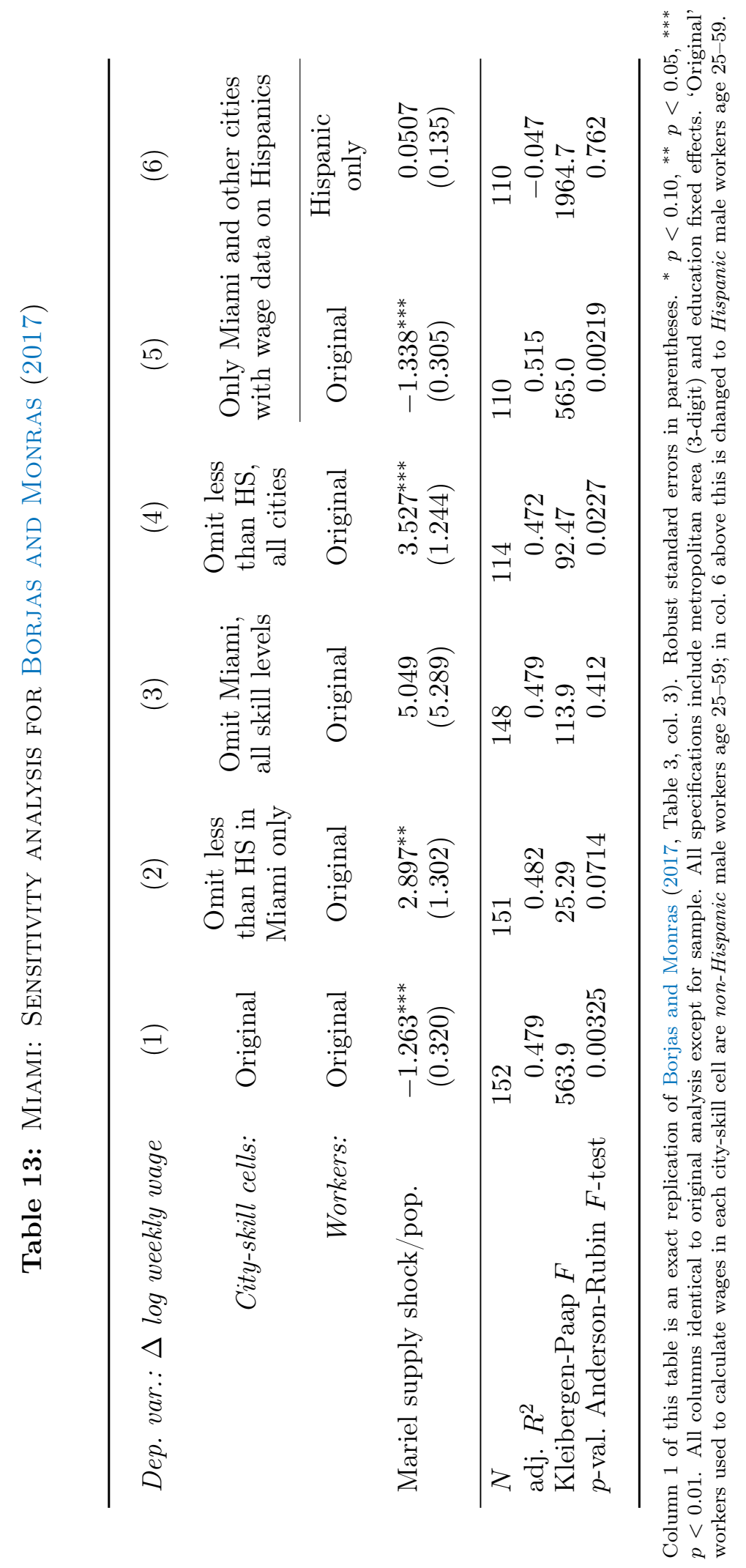




\section{Appendix}

\section{A Additional evidence of compositional change}

Appendix Table 1 shows a falsification test for the differences-in-differences regressions in Borjas (2017, Table 5). It is identical to those regressions except for the dependent variable. In the original regressions the dependent variable is the city-period average log wage; here, the dependent variable is the city-period average years of education (within the subgroup of workers with less than high school). This is a falsification test because the true treatment effect must be essentially zero: the sample only includes men age 25 and over, whose education decisions are fixed. But there is a large, negative, false treatment effect: the Boatlift appears to 'cause' a reduction in the average schooling of this subpopulation by about half a year of education. This decline is statistically significant relative to the Card control cities, but not the Borjas control cities. This evidence suggests important negative selection into the subsample contemporaneous with the Boatlift.

\section{Appendix Table 1: Falsification test With outcome as years of education}

\begin{tabular}{|c|c|c|}
\hline \multirow{4}{*}{$\begin{array}{l}\text { Dep. var.: } \\
\text { Control cities: } \\
\text { 1981-83 }\end{array}$} & $(1)$ & $(2)$ \\
\hline & \multicolumn{2}{|c|}{ Years of education } \\
\hline & Card & Borjas \\
\hline & $\begin{array}{c}-0.348 \\
(0.446)\end{array}$ & $\begin{array}{c}-0.124 \\
(0.573)\end{array}$ \\
\hline $1984-86$ & $\begin{array}{r}-0.444 \\
(0.267)\end{array}$ & $\begin{array}{c}-0.142 \\
(0.514)\end{array}$ \\
\hline $1987-89$ & $\begin{array}{c}-0.562^{* *} \\
(0.230)\end{array}$ & $\begin{array}{c}-0.422 \\
(0.418)\end{array}$ \\
\hline $1990-92$ & $\begin{array}{c}0.0578 \\
(0.964)\end{array}$ & $\begin{array}{c}0.384 \\
(0.936)\end{array}$ \\
\hline $\begin{array}{l}N \\
\text { adj. } R^{2}\end{array}$ & $\begin{array}{l}75 \\
0.310\end{array}$ & $\begin{array}{l}75 \\
-0.029\end{array}$ \\
\hline
\end{tabular}

Difference-in-difference regressions with pre-treatment period 1977-79. Year 1980 omitted since it includes both pre-treatment and post-treatment observations, as in Borjas (2017, Table 5). Unit of observation is city-period. Dependent variable is years of education. Robust standard errors in parentheses: ${ }^{*} p<0.10,{ }^{* *} p<0.05,{ }^{* * *} p<0.01$. Sample is working non-Hispanic males age 25-59 with less than high school. The Card preferred control cities are Atlanta, Los Angeles, Houston, and Tampa-St. Petersburg; the Borjas preferred control cities are Anaheim, Rochester, Nassau-Suffolk, and San Jose.

\section{B Compositional change in the March CPS versus May/MORG}

Why would CPS coverage of low-skill blacks rise more in the March CPS than in the MORG? The March CPS Annual Social and Economic Supplement (ASEC) data come from a one-off survey that is not repeatedly applied to the same households. The MORG data, in contrast, are gathered from households that have been interviewed repeatedly in a panel over a period of time that 
extends over either 4 or 16 months. ${ }^{38}$ It is well known that households in the CPS panel exhibit a net reduction in reported members during the panel: "people leaving a household are correctly identified, but new people entering a household are not always recorded" (Hainer et al. 1988, 517). This non-replaced individual attrition is highest for those only loosely connected to the reference person. In CPS data from 2006-2012, it is $11 \%$ for nonrelatives of the reference person who start out the panel living at the residence without their own relatives (Robison and Grieves 2014, 1344).

Such attrition would likely have been larger in the 1980s, and almost certainly larger in low-skill black households than the average. Low-skill black men in inner-city households are much more likely than others to exhibit individual attrition from the CPS panel (Neumark and Kawaguchi 2004). These are many of the same low-skill black men in poor, inner-city neighborhoods who "have tenuous or irregular ties with one or more households, but do not 'usually' live anywhere" (Hainer et al. 1988, 525). Many are not reported at all by the overwhelmingly female survey respondents in those neighborhoods - including almost a quarter of 25 year-old black men in the early 1980s (Hainer et al. 1988) - unless probing questions are asked by specially-trained interviewers.

In other words, the undercount of low-skill black men would be most responsive to efforts to increase coverage by more probing initial interviews about who lives at the residence, such as in the one-off March CPS or at the initial interview of an incoming rotation group. But the same people are among the most likely to disappear from the household roster by the time that earnings questions are asked of the panel's outgoing rotation group.

\section{Comparing coefficient estimates in the various studies}

Friedberg (2001) and Borjas and Monras (2017) employ what is known as the skill-cell approach to the impact of immigration. This uses variation in the density of immigrants across worker groups defined by education and another dimension (geography, in the case of Borjas and Monras, occupation in the case of Friedberg). The resulting regression coefficient should be interpreted as the impact of immigrants of a particular skill on immigrants with the same skill, averaged across skills. It does not represent the impact of all immigrants on all natives (the effect studied by Hunt 1992), because it omits the impacts of immigrants of a particular skill on natives with different skills. We ignore this difference when comparing results from skill-cell studies with the Hunt (1992) coefficients. On the other hand, we do adjust the Hunt coefficient, which reflects the impact of the share of immigrants (in the labor force), to correspond to the Borjas and Monras and Friedberg coefficients, which reflect the impact of the ratio of immigrants to natives (in the skill-cell). To do so, we multiply the Hunt coefficients $(\gamma)$ by $(1-p)^{2}$, where $p=0.016$ is the aggregate share of immigrants in the French labor force; in practice, this multiplication by 0.97

\footnotetext{
${ }^{38}$ After rotating into the panel housing units' occupants are interviewed once a month for four months, ignored for eight months, then again interviewed once a month for four months. Questions about weekly earnings are only asked of the outgoing rotation groups at the fourth interview (month four) and eighth interview (month 16). Housing units are followed in the panel rather than people, so that if a new family moves into the address during the panel they become the survey respondents.
} 
makes little difference. Proof:

$$
\begin{aligned}
\frac{\partial u}{\partial(M / N)} & =\frac{\partial u}{\partial(M /(M+N))} \frac{\partial(M /(M+N))}{\partial(M / N)} \\
& =\gamma \frac{\partial}{\partial(M / N)} \frac{M / N}{1+M / N} \\
& =\gamma \frac{1}{(1+M / N)^{2}} \\
& =\gamma(1-p)^{2}
\end{aligned}
$$

A more quantitatively important adjustment is made to the coefficients from the Kronmal-corrected specifications to make them comparable to the Borjas and Monras and Friedberg coefficients. To do so, we multiply the coefficient on the inverse hyperbolic sine of immigrants $(\theta)$ by $(1-p) / p$, where $p$ is the immigrant share. Proof:

$$
\begin{aligned}
\frac{\partial u}{\partial(M / N)} & =\frac{\partial u}{\partial \log M} \frac{\partial \log M}{\partial(M / N)} \\
& =\frac{\theta}{M} \frac{\partial M}{\partial(M / N)} \\
& =\theta /(M / N) \\
& =\theta \frac{1-p}{p} .
\end{aligned}
$$

Appendix Table 2 uses these relationships to show the coefficient estimates from the main text in comparable terms. 


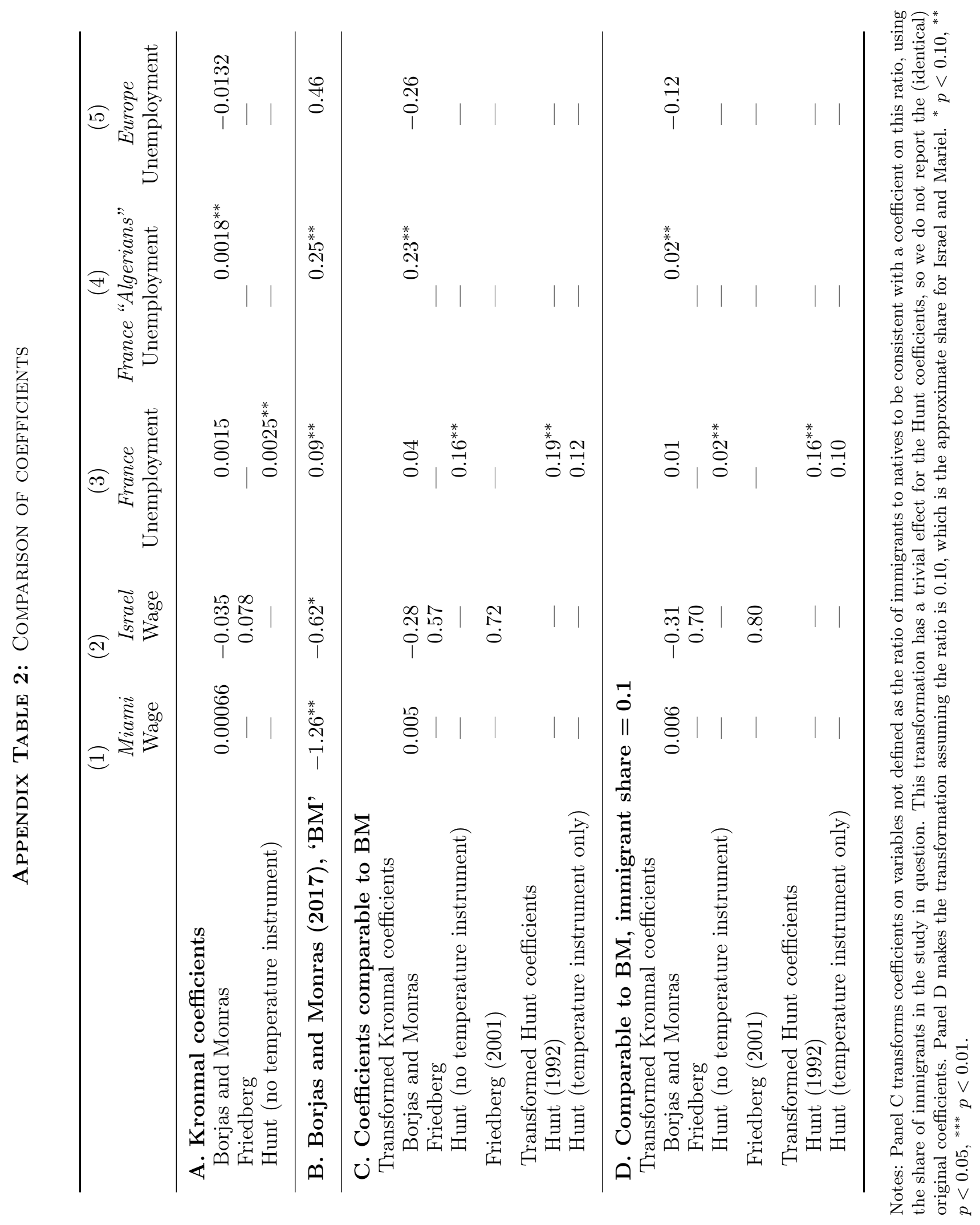




\section{Online Supplement \\ "The Labor Market Effects of Refugee Waves Reconciling Conflicting Results"}

\section{A Placebo and Kronmal-corrected regressions for Miami}

Here we present reanalysis of the Miami regressions in Borjas and Monras (2017) mirroring the reanalyses in the main text of the Israel, France, and Europe studies. Supplement Table 1 shows the placebo regressions. Supplement Table 2 shows the Kronmal specification correction.

Supplement Table 1: Miami: Placebo Regressions

(a) Miami: Mean 1977-1979 Cuban stock by education, real vs. placebo

\begin{tabular}{lrr}
\hline Education & Real & Placebo \\
\cline { 2 - 3 } Less than high school & 4912.2 & 4913.6 \\
High school & 2594.9 & 2599.2 \\
Some college & 1693.0 & 1698.3 \\
College graduate & 1293.6 & 1300.5 \\
\hline
\end{tabular}

The placebo is a randomly-generated variable drawn from a Poisson distribution with the same mean as the real variable.

(b) Miami: Placebo reanalysis of Borjas E Monras Table 3, cols. 3 and 4

\begin{tabular}{lcccc}
\hline Dep. var.: $\Delta$ log weekly wage & $(1)$ & $(2)$ & $(3)$ & $(4)$ \\
\multicolumn{1}{c}{ Lagged Cuban fraction $I V:$} & Real & Placebo & Real & Placebo \\
\cline { 2 - 5 } & & & & \\
Mariel supply shock/pop. & $-1.263^{* * *}$ & -6.058 & $-1.310^{* * *}$ & -4.350 \\
& $(0.320)$ & $(10.58)$ & $(0.322)$ & $(8.250)$ \\
Change in native population & & & 0.0385 & 0.0606 \\
& & & $(0.0382)$ & $(0.0739)$ \\
\hline$N$ & 152 & 152 & 152 & 152 \\
adj. $R^{2}$ & 0.479 & 0.063 & 0.478 & 0.311 \\
Kleibergen-Paap $F$ & 563.9 & 1.609 & 561.3 & 1.450 \\
$p$-val. Anderson-Rubin $F$-test & 0.00325 & 0.608 & 0.00265 & 0.652 \\
\hline
\end{tabular}

Robust standard errors in parentheses. ${ }^{*} p<0.10,{ }^{* *} p<0.05,{ }^{* * *} p<0.01$. The instrument set in each column is: (1) real 1977-79 Cuban fraction, (2) placebo 1977-79 Cuban fraction, (3) real 1977-79 Cuban fraction, (4) placebo 1977-79 Cuban fraction. All specifications include metropolitan area (3-digit) and education fixed effects. 
Supplement Table 2: Miami: Kronmal specification correction

(1)

Dependent variable:

Estimator:

Mariel supply shock/pop.

asinh Mariel supply shock/pop.

asinh Mariel supply shock

asinh total pop. (without Mariel)
(2)

$\Delta \log$ weekly wage

(3)

(4)

asinh Mariel supply shock

OLS

$-1.263^{* * *}$
$(0.320)$

